\title{
Rien ne Va Plus? Distinguishing domestic regulation from market access in GATT and GATS
}

\author{
JOOST PAUWELYN* \\ Associate Professor, Duke University School of Law
}

\begin{abstract}
Depending on how one classifies market intervention, trade liberalization disciplines can be lenient or strict. Perhaps the most important distinction in this respect is that between government intervention labeled as a 'market access restriction' and that defined as 'domestic regulation'. Both the GATT and the GATS declare market access restrictions (such as import quotas or limitations on the number of service suppliers) to be, in principle, prohibited. In contrast, domestic regulations (such as internal taxes, health standards, and safety requirements) are treated with much more deference. They are, in essence, only prohibited when discriminatory or more trade restrictive than necessary.

Notwithstanding these major legal consequences, the distinction between market access and domestic regulation remains unclear. Based on a recent WTO dispute condemning the United States for banning online gambling, this article is an attempt to clarify the distinction. Starting from broad similarities, it finds crucial differences in this respect between GATT and GATS. For both, however, the paper's basic point is that a domestic regulation should not be regarded as a market access restriction simply because it has the effect of banning certain imports. To do otherwise risks seriously undermining the regulatory autonomy of WTO Members beyond anything imagined by the drafters of the WTO treaty.
\end{abstract}

\section{Introduction}

On 7 April 2005, the World Trade Organization (WTO) condemned the United States for banning online gambling. ${ }^{1}$ It did so at the request of one of the smallest

\section{Correspondence: Email: PAUWELYN@law.duke.edu}

* I am extremely grateful for comments and discussions with Lorand Bartels, Steve Charnovitz, Markus Krajewski, Simon Lester, Jan Yves Remy, Joel Trachtman and the anonymous reviewers of the World Trade Review. All errors remain mine alone.

1 Appellate Body Report on United States - Measures Affecting the Cross-Border Supply of Gambling and Betting Services ('US - Gambling'), WT/DS285/AB/R, circulated on 7 April 2005, partly reversing the earlier Panel Report on US - Gambling, WT/DS285/R, circulated on 10 November 2004. For a brief discussion of these two reports, see, respectively, Joost Pauwelyn, 'WTO Condemnation of U.S. Ban on Internet Gambling Pits Free Trade against Moral Values', ASIL Insight, November 2004, available at http://www.asil.org/insights/2004/11/insight041117.html and Joost Pauwelyn, 'WTO Softens Earlier Condemnation of U.S. Ban on Internet Gambling, but Confirms Broad Reach into Sensitive Domestic Regulation', ASIL Insight, April 2005, available at http://www.asil.org/insights/2005/04/insights050412. html. 
countries in the world, Antigua and Barbuda. Antigua brought its complaint to the WTO after Jay Cohen, a US citizen and operator of an internet sports-book service based in Antigua, was jailed in the United States for the remote supply of gambling services in violation of the 1961 US Wire Communications Act. ${ }^{2}$

This paper does not address whether the United States did, indeed, make specific commitments for gambling services under the General Agreement on Trade in Services (GATS). ${ }^{3}$ Nor does it deal with the panel's controversial rejection of the US defense (only partly reversed by the Appellate Body) that its gambling laws are 'necessary to protect public morals or to maintain public order'. ${ }^{4}$ The question of whether the United States, either in law or effect, discriminates against foreign gambling suppliers is also left open..$^{5}$ Instead, the paper raises a systemic argument of considerable importance for the future of the GATS. It runs as follows. Even if the United States did make specific commitments on gambling, the US ban on remote gambling is not, as both the panel and the Appellate Body found, a 'market access restriction' that is, in principle, prohibited under Article XVI of GATS. Rather, it is a 'domestic regulation' subject to Articles VI and XVII of GATS, more particularly, a technical standard applying to both foreign and US suppliers that prescribes how gambling services must be performed in the United States.

To construe trade-related policies as market access restrictions, whilst they are in fact domestic regulation - as, in my view, occurred in US - Gambling - has major legal consequences. In contrast to more integrated trade liberalization schemes such as the European Union or the United States, ${ }^{6}$ both the GATS and the General Agreement on Tariffs and Trade (GATT) make crucial distinctions between market access restrictions and domestic regulation. In essence, where commitments are made, market access restrictions are, in principle, prohibited. ${ }^{7}$ Domestic regulation, in contrast, is subject to broad regulatory autonomy and, as a rule, violates GATT or GATS only when it discriminates against imports.

Notwithstanding this basic distinction in two of the main pillars of the WTO, the boundaries between market access and domestic regulation remain

2 United States v. Cohen, 260 F.3d 68 (2nd Cir. 2001), cert. Denied 122 S.Ct. 2587 (2002).

3 As both the Panel and the Appellate Body concluded pursuant to GATS Article XVI and the US schedule of GATS commitments. See Panel and Appellate Body Report on US - Gambling, respectively, para. 6.134 and para. 213.

4 Pursuant to Article XIV of GATS. See Panel and Appellate Body Report on US - Gambling, respectively, para. 6.608 and para. 372. Eventually, the Appellate Body rejected the US defense only for failure to meet the non-discrimination standard in the chapeau of GATS Article XIV, more specifically, because it was not convinced that the United States was treating foreign and domestic service suppliers equally under its Interstate Horseracing Act.

5 Pursuant to the national treatment obligation in Article XVII of GATS, a question eventually not addressed in the panel report for reasons of judicial economy. See Panel Report on US-Gambling, para. 6.426 .

6 See infra Section 2.3.

7 Unless justified under explicit exceptions, in particular, the exhaustive list of legitimate policy objectives in GATT Articles XX/XXI or GATS Articles XIV/XIVbis. 
unsettled. This paper is an attempt to draw those boundaries using, in particular, the example of the US - Gambling case. Far beyond the specifics of the Gambling dispute, a correct classification of policy instruments under WTO law is important for a wide range of market interventions, be it to protect public morals, health, the environment, or national security. Driven to its logical conclusion, the approach in US-Gambling risks WTO intrusion into the regulatory freedom of WTO Members far beyond what was originally agreed to in the WTO Treaty. ${ }^{8}$ The classification is crucial also for ongoing negotiations on disciplines for domestic regulation under Article VI:4 of GATS. Essentially, if the scope of market access restrictions under Article XVI of GATS were defined too broadly, as risks being the case after US - Gambling, scores of domestic regulations would already be prohibited and the ongoing negotiations would lose much of their purpose.

Section 2 of this paper explains the distinction between market access and domestic regulation. It highlights similarities - as well as some crucial differences - between GATT and GATS, and contrasts the WTO approach with the more integrated systems of EC and US law where the distinction is largely absent. Section 3 elaborates on how the two disciplines are circumscribed and interact, first in GATT, then in GATS. At this juncture, additional differences between the GATT and GATS become apparent. To provide a concrete example, Section 4 applies the position defended in this paper to the US laws in the Gambling dispute. Section 5 summarizes the paper's main findings.

\section{The distinction between market access and domestic regulation}

Both GATT and GATS make important distinctions between types of government policies that may restrict trade. Those distinctions are not merely legal niceties. They reflect both economic and political preferences of certain types of policies over others and lead to drastically different disciplines and restrictions on the regulatory autonomy of WTO Members. Depending solely on how a government measure is categorized, the measure may therefore be permitted or prohibited under WTO law. Put differently, when misinterpreting those distinctions (as, in my view, the Panel and the Appellate Body did in US - Gambling), the risk is that WTO violations are found where the drafters of the WTO treaty envisaged broad regulatory autonomy.

\subsection{Market access versus domestic regulation under GATT}

Under GATT the crucial dividing line amongst policy instruments affecting trade is between, on the one hand, measures imposed at the border or on importation

8 Hence, the title of this paper Rien Ne Va Plus (which can be translated from the French as 'from now on nothing is possible') alluding both to (i) the risk that, after Gambling, scores of domestic regulations may be inconsistent with GATS, and (ii) the phrase used in casinos to signal that 'bets are off'. 
and, on the other hand, measures affecting imports once they have cleared customs. The former - often referred to as 'border measures' or 'market access restrictions' - are covered by Articles II and XI of GATT, addressing, respectively, custom duties and other duties or charges imposed on or in connection with importation (Article II) and quantitative import prohibitions or restrictions (Article XI). The latter - commonly referred to as 'behind the border measures' or 'domestic regulation' - are dealt with in Article III addressing internal taxation (such as VAT or sales taxes) and other internal regulations (such as safety requirements or sales regulations).

The legal consequences linked to those GATT distinctions are vital. Most importantly, whilst market access measures taking the form of quantitative restrictions are, in principle, prohibited (pursuant to Article XI), GATT parties reserved their sovereign prerogative to set domestic regulation, be it internal taxes, safety standards, or sales requirements, on the sole condition that such regulation does not favor domestic products over imports (pursuant to Article III). Put differently, when a measure is found to be a border measure subject to Article XI, it is prima facie prohibited. In contrast, when the measure is qualified as a domestic regulation under Article III, it can only be found afoul of GATT rules when it is discriminatory. ${ }^{\mathbf{9}}$

Sound economic and political reasons for the GATT distinction between market access and domestic regulation are readily available. In economic terms, border or market access measures - be it custom duties or import quotas - by definition only apply to imports and can therefore be presumed to be imposed for protectionist purposes. Since protectionist measures are, in general, economically wasteful and harmful to both foreign producers and domestic consumers, there is a strong case to prohibit them or, at least, to gradually reduce them (as is the case for tariffs). ${ }^{10}$ Domestic regulation, in contrast, most often serves legitimate, non-protectionist purposes, be it consumer protection, safety, or health. As a result, it made sense for the GATT to overrule domestic regulation only when it is proven to be protectionist, more particularly, when it discriminates against imports, that is, when it

9 Both violations of Article XI and Article III can, however, be justified under specific GATT exceptions. Importantly, given the per se prohibition in Article XI, the list of exceptions under Article XI is longer than that under Article III. The former includes not only GATT Articles XX and XXI (general and security exceptions), but also GATT Articles XI:2, XII (balance of payments restrictions) and XIII-XIV (discriminatory and non-discriminatory quotas). In this sense, to construe a measure as an Article XI quantitative restriction not only has benefits for the complainant, it may also offer more leeway for the party enacting the measure: Although an Article XI measure is prima facie prohibited, the list of potential justifications for it is broader.

10 The GATT thereby expresses a clear preference for tariffs (subject only to tariff ceilings) over quotas (which are, in principle, prohibited), a position that is supported by economic theory. See Arthur Dunkel and Frieder Roessler, 'The Ranking of Trade Policy Instruments under the GATT Legal System' (on file with the author) and Alan Sykes, 'Regulatory Protectionism and the Law of International Trade', 66 University of Chicago Law Review 1 (1999). 
imposes so-called deadweight costs on foreign firms that are not imposed on domestic firms. ${ }^{11}$

In political terms, the distinction is equally palatable. Whilst most border measures, such as tariffs or quotas, serve purely economic interests, in particular, the protection of national industries, much domestic regulation goes to the social and political heart of a country's sovereignty, addressing sensitive areas such as health and consumer protection, environmental concerns and income redistribution through taxation. Consequently, WTO Members felt more at ease committing to the elimination or reduction in tariffs and quantitative import restrictions, than tying their hands in the politically more sensitive field of domestic regulation. As market access restrictions can be seen as pure trade measures, they fall squarely within the mandate of the GATT. The GATT has, in contrast, little to say about how nations assess domestic market failure as long as they do so in a non-discriminatory manner.

Only with the creation of the 1994 WTO agreements on sanitary and phytosanitary measures (SPS) and technical barriers to trade (TBT) did disciplines on domestic regulation move beyond the rule of non-discrimination. ${ }^{12}$ Indeed, under the SPS and TBT agreements, even a measure that is not discriminatory, i.e., treats imports and domestic products alike both de jure and de facto, can still breach SPS or TBT disciplines if it is, for example, not based on a risk assessment (SPS Article 5.1) or more trade restrictive than necessary to protect human health (SPS Article 5.6) or to fulfill any other legitimate, non-protectionist objective (TBT Article 2.2). However, as GATT continues to apply in tandem with SPS and TBT rules, the distinction between market access and domestic regulation remains crucial. ${ }^{13}$

\subsection{Market access versus domestic regulation under GATS}

Unlike the physical movement of goods across borders, the intangible nature of services (ranging from banking and telecommunications to distribution and construction) means that they generally escape the physical control of customs officials. As a result, countries wanting to protect their domestic services industry cannot normally impose the traditional trade in goods instruments of tariffs or import quotas. ${ }^{14}$ Yet, for the same economic and political reasons explained

11 Note, however, that when domestic regulation does discriminate against imports, it constitutes the least efficient form of protection as compared with all other forms of protection. See Dunkel and Roessler, supra note 11 and Sykes, supra note 10.

12 GATT Article X on publication and impartial administration of trade regulations is an exception to this rule. From GATT's inception in 1947 this transparency provision did apply to all trade regulations, including non-discriminatory domestic regulations.

13 See Joost Pauwelyn, 'Cross-agreement Complaints before the Appellate Body: A Case Study of the EC - Asbestos Dispute', 1 World Trade Review (2002), 63.

14 For a background to the GATS, see Aaditya Mattoo, 'Shaping Future Rules for Trade in Services, Lessons from the GATS' (mimeo, World Bank, July 2000) and Pierre Sauve and Robert Stern (eds), GATS 2000: New Directions in Services Trade Liberalization (Washington, DC: Brookings, 2000). 
earlier, the GATT distinction between market access and domestic regulation has its functional equivalent also under GATS.

Like tariffs and import quotas under GATT, government intervention in the services industry that quantitatively restricts the very access or establishment of foreign services or service suppliers to a country's domestic market, is subject to a different discipline than so-called domestic regulations addressing the quality of a service or its supplier. The former, market access restrictions, are dealt with in Article XVI of GATS. The latter, domestic regulations, are addressed predominantly in Articles VI, XVII and XVIII of GATS. ${ }^{15}$

As is the case under GATT, the distinction thus made by GATS between market access and domestic regulation has vital legal consequences. Like quantitative restrictions under Article XI of GATT, the market access restrictions specified in Article XVI of GATS ${ }^{16}$ are, for committed services sectors ${ }^{17}$ in principle, probibited (unless they are explicitly listed in the Member's schedule). In contrast, like domestic regulations under Article III of GATT, domestic regulations affecting the supply of services are, in principle, permitted on condition that they do not discriminate foreign as against domestic services or service suppliers. ${ }^{18}$

15 For literature on domestic regulation under GATS, see Aaditya Mattoo and Pierre Sauve (eds), Domestic Regulation and Service Trade Liberalization (Washington, DC: World Bank 2003) and Markus Krajewski, National Regulation and Trade Liberalization in Services: The Legal Impact of the GATS on National Regulatory Autonomy (Kluwer Law International, 2003).

16 GATS Article XVI enumerates six prohibited market access restrictions for those services where a WTO Member made market access commitments:

(a) limitations on the number of service suppliers whether in the form of numerical quotas, monopolies, exclusive service suppliers or the requirements of an economic needs test;

(b) limitations on the total value of service transactions or assets in the form of numerical quotas or the requirement of an economic needs test;

(c) limitations on the total number of service operations or on the total quantity of service output expressed in terms of designated numerical units in the form of quotas or the requirement of an economic needs test;

(d) limitations on the total number of natural persons that may be employed in a particular service sector or that a service supplier may employ and who are necessary for, and directly related to, the supply of a specific service in the form of numerical quotas or the requirement of an economic needs test;

(e) measures which restrict or require specific types of legal entity or joint venture through which a service supplier may supply a service; and

(f) limitations on the participation of foreign capital in terms of maximum percentage limit on foreign shareholding or the total value of individual or aggregate foreign investment.

17 That is, services sectors explicitly listed in a Member's schedule in the Article XVI market access column. For sectors not so listed, WTO Members maintain the right to impose market access restrictions.

18 Pursuant to Article XVII of GATS which is, moreover (in contrast to national treatment under GATT) only triggered for committed services sectors and is subject to explicit exceptions in a Member's schedule. One possible reason for this distinction between GATT and GATS is that both agreements recognize the need (mainly political) for some protectionism. In GATT, this need is channeled predominantly through the tariff instrument; in GATS, where tariffs are not a readily available instrument, such protection, by default, is more likely to take the form of discriminatory regulation. As a result, reservations under GATS national treatment became crucial. 
Comparable with the SPS and TBT agreements for trade in goods, Articles VI and XVIII of GATS add further discipline for domestic service regulations, in particular those that are not discriminatory. Put differently, even a service measure that does not qualify as a market access restriction under Article XVI and does not discriminate foreign as against domestic services or service suppliers under Article XVII, can still run afoul of GATS. First, under Article XVIII it may violate a so-called additional commitment specifically inscribed in a Member's schedule (such as the competition-type rules in the telecom sector committed to by a number of WTO Members). ${ }^{19}$ Second, under Article VI the measure may be inconsistent with the transparency and impartial administration requirements of paragraphs 1 to 3 , or be found to restrict trade more than necessary contrary to paragraph $5^{20}$

However, like the SPS and TBT disciplines for trade in goods, which were only established decades after the GATT's original conclusion in 1947, most of the rules and restrictions in respect of domestic service regulations remain to be set in ongoing and future GATS negotiations. In particular, pursuant to Article VI:4 of GATS, the Council for Trade in Services is to 'develop any necessary disciplines', with a view to 'ensuring that measures relating to qualification requirements and procedures, technical standards, and licensing requirements do not constitute unnecessary barriers to trade in services'. In 1998, the GATS Council adopted the first, and so far only, set of disciplines under Article VI:4 applicable to domestic regulation in the accountancy sector. ${ }^{21}$ Awaiting the adoption of further disciplines, Article VI:5 only prohibits licensing, qualification, and technical requirements that (i) nullify specific commitments made by the WTO Member concerned under Articles XVI-XVIII by means of (ii) unnecessary barriers to trade, as defined in the broad guidelines of Article VI:4, ${ }^{22}$ and (iii) could not reasonably have been expected at the time those specific GATS commitments were made. ${ }^{23}$

19 See the Panel Report on Mexico - Measures Affecting Telecommunications Services, WT/DS204/R, adopted 1 June 2004 (not appealed).

20 Crucially, however, with the exception of paragraphs 2 and 4, all Article VI disciplines on domestic regulation only apply in those services sectors for which the WTO Member in question made specific commitments under Articles XVI-XVIII.

21 Disciplines on Domestic Regulation in the Accountancy Sector, Decision of the GATS Council of 14 December 1998, S/L/64.

22 The Article VI:4 guidelines require that future disciplines on domestic regulation aim to ensure that such regulations are:

(a) based on objective and transparent criteria, such as competence and the ability to supply the service;

(b) not more burdensome than necessary to ensure the quality of the service;

(c) in the case of licensing procedures, not in themselves a restriction on the supply of the service.

23 See infra text at notes 127 and 128. 
Crucially, therefore, at this stage GATS negotiators explicitly refused to impose a general necessity test on non-discriminatory domestic regulation. ${ }^{24}$ With the exception of the accountancy sector, any such test remains to be developed. What the Panel (and to a lesser extent the Appellate Body) ${ }^{25}$ on US-Gambling did, however, was to impose such a test through the backdoor, that is, by finding, first, that the US gambling laws are prohibited market access restrictions and, second, failing those laws under the necessity test in the Article XIV exceptions on, inter alia, public morals. ${ }^{26}$ In the process, the Panel even went beyond any to-bedeveloped necessity requirement, by shifting the burden of proving necessity from Antigua to the United States and limiting the substantive grounds for justification to the exhaustive list in Article XIV (instead of the more open list of Article VI: 4 and the Accountancy Guidelines).

This highlights another reason to carefully distinguish between market access and domestic regulation under GATS: namely, the available range of exceptions or policy objectives that may justify the trade restriction and the burden of proof that comes with it. ${ }^{27}$ Violations of Article XVI (market access) and Article XVII (national treatment) can only be justified under the exhaustive list of exceptions in Articles XIV and XIV bis (general and security exceptions). Moreover, the burden of proof under those exceptions rests on the defendant (the Member enacting the measure), i.e. it is for the defendant to demonstrate that the measure is necessary to protect public morals. In contrast, similar to the open list of policy objectives in TBT Article 2.2, the list of potential justifications under Article VI of GATS and the Accountancy Guidelines is broader ${ }^{28}$ Article VI:4 refers to 'objective and transparent criteria, such as competence and the ability to supply the service' and to measures 'not more burdensome than necessary to ensure the quality of the service', without defining what factors or objectives can be considered under quality. Moreover, the burden of proof under Article VI rests on the complainant, i.e., it is for the complainant to demonstrate that the measure is not necessary for its stated objective. In addition, even if a measure violates Article VI, it can, in theory, still be justified under the general exceptions of Articles XIV/XIV bis,

24 Unlike the first draft of the GATS (MTN.GNS/35 of 23 July 1990, Article VII), which contained the following necessity requirement for all domestic regulation:

Parties may require that services or providers of services of other parties meet certain regulations, standards or qualifications. Such requirements shall be based upon objective criteria, such as competence and the ability to provide such services, and not be more burdensome than necessary to achieve the national policy objectives. (emphasis added)

25 As noted supra note 4, the Appellate Body did not fault the US laws on the ground that they were not 'necessary' under Article XIV, but rather because their application was discriminatory under the chapeau of Article XIV.

26 Panel Report on US - Gambling, paras. 6.535 and 6.565 .

27 For a similar analysis under GATT, see supra footnote 9.

28 Compare in this respect, TBT Article 2.2 with paragraph 2 of the Accountancy Disciplines. Both refer to 'a legitimate objective' and then provide a non-exhaustive list of legitimate objectives. 
although in practice this may be difficult. ${ }^{29}$ Finally, it must be kept in mind that, whilst measures contrary to GATS Articles XVI and XVII can be scheduled (that is, explicitly listed as reserved under a Member's market access or national treatment column), violations under Article VI (domestic regulation) cannot be scheduled. ${ }^{30}$

The distinctions thus made at the WTO between trade policy instruments and how GATT and GATS generally compare in this respect, are summarized in Table $1 .^{31}$

\subsection{Contrast with the EC Treaty and the US Dormant Commerce Clause}

The important distinctions thus made at the WTO between market access and domestic regulation stand in sharp contrast to the more uniform liberalization of trade in more integrated regimes such as the European Union or the United States.

The Treaty Establishing the European Community ('EC Treaty'), for example, does not have a separate provision dealing with domestic regulation (similar to GATT Article III:4). At the border, it bans customs duties and 'all charges having equivalent effect ${ }^{32}$ (in contrast to GATT Article II, which only prohibits tariffs that exceed a country's bindings). The EC Treaty also prohibits the discrimination of imports, both direct and indirect, through internal taxation. ${ }^{33}$ However, it lumps together the distinction made in GATT between quantitative import restrictions (GATT Article XI) and domestic regulation affecting imports (GATT Article III:4). It does so in its Article 28, which prohibits '[q]uantitative restrictions on imports and all measures having equivalent effect'. The latter has been interpreted broadly to include '[a]ll trading rules enacted by Member States which are capable of hindering, directly or indirectly, actually or potentially, intraCommunity trade'. ${ }^{34}$ In other words, Article 28 includes quotas or restrictions on importation and domestic regulation that also restricts imports. ${ }^{35}$

29 First, whilst Article VI:4 seems to offer a relatively open list of legitimate policy objectives, Article XIV (much like GATT Article XX) offers a closed list of objectives. If the measure does not fit under an open list, it is unlikely to fit under a closed list. Second, although Article VI refers to a basis in 'objective and transparent criteria', it does not include the non-discrimination and other requirements that the chapeau of Article XIV imposes (i.e. the ultimate and only ground on which the Appellate Body faulted the US gambling laws). To some extent, and quite paradoxically, the exception (Article XIV) may thus be more difficult to meet than the rule (Article VI).

30 See Scheduling of Initial Commitments in Trade in Services: Explanatory Note, MTN.GNS/W/164, 3 September 1993, para. 5 (hereafter '1993 Scheduling Guidelines').

31 See also Gabrielle Marceau and Joel Trachtman, ‘TBT, SPS, and GATT: A Map of the WTO Law of Domestic Regulation', 36 Journal of World Trade (2001), 811 and Joel Trachtman, Lessons for the GATS from Existing WTO Rules on Domestic Regulation, in Mattoo and Sauve, supra note 15, at 57.

32 Article 23 EC Treaty.

33 Article 90 EC Treaty.

34 Procureur du Roi v. Dassonville, Case 8/74, [1974] ECR 837, para. 5.

35 For a further comparison between EC and WTO rules in this respect, see Jochem Wiers, Trade and Environment in the EC and the WTO: A Legal Analysis (Groningen: Europa Law Publishing, 2004), 46. 
Table 1.

\begin{tabular}{|c|c|c|c|}
\hline & DISCIPLINE & GATT - GOODS & GATS - SERVICES \\
\hline $\begin{array}{l}\text { MARKET } \\
\text { ACCESS restrictions }\end{array}$ & $\begin{array}{c}\text { in principle, } \\
\text { prohibited }\end{array}$ & $\begin{array}{l}\text { *Article II } \\
\text { (subject to tariff } \\
\text { bindings) } \\
\text { *Article XI }\end{array}$ & $\begin{array}{l}\text { Article XVI (subject to } \\
\text { commitments) }\end{array}$ \\
\hline \multirow[t]{2}{*}{$\begin{array}{l}\text { DOMESTIC regulation } \\
\text { (including taxes) }\end{array}$} & $\begin{array}{l}\text { non-discrimination } \\
\text { (national treatment) }\end{array}$ & Article III & $\begin{array}{l}\text { Article XVII (subject } \\
\text { to commitments) }\end{array}$ \\
\hline & $\begin{array}{l}\text { transparency, } \\
\text { necessity, etc. even } \\
\text { for non-discriminatory } \\
\text { measures }\end{array}$ & $\begin{array}{l}\text { *Article X } \\
* \text { SPS agreement } \\
* \text { TBT agreement }\end{array}$ & $\begin{array}{l}\text { *Article VI (subject } \\
\text { to commitments) } \\
\text { *Article XVIII } \\
\text { (subject to commitments) } \\
\text { "Disciplines (to be) } \\
\text { developed by the } \\
\text { GATS Council }\end{array}$ \\
\hline
\end{tabular}

Equally, the so-called Dormant Commerce Clause in the US Constitution ${ }^{36}$ can, in principle, cover all state measures that impede the flow of interstate commerce whether they take the form of border measures or internal regulation. If the statute facially discriminates against interstate commerce it is deemed 'virtually per se invalid' ${ }^{37}$ However, even if there is no facial discrimination the statute can be struck down if 'the burden imposed [on interstate commerce]... is clearly excessive in relation to the putative local benefit' ${ }^{38}$

36 US CONST. art. I, § 8, cl. 3, which expressly grants Congress the power ' $[\mathrm{t}]_{\mathrm{o}}$ regulate Commerce... among the several states'.

37 Oregon Waste Sys., Inc. v. Dep't of Envtl. Quality, 511 US 93, 99 (1994).

38 Pike v. Bruce Church, 397 US at 142. Because of their broad coverage - including market access restrictions and domestic regulation, discriminatory and non-discriminatory measures - the exceptions available under EC and US law to justify facially prohibited measures are much broader than those in the exhaustive lists of GATT Articles XX and XXI (and GATS Articles XIV and XIV bis). In the EC, measures that are not discriminatory do not violate Article 28 of the EC Treaty if they are 'necessary in order to satisfy mandatory requirements', essentially any legitimate policy objective (Cassis de Dijon, Case 120/78, [1979] ECR 649, para. 9). Case law under the US Dormant Commerce Clause refers to any 'legitimate local public interest' (Pike v. Bruce Church, 397 US at 142). The additional disciplines for domestic regulation under the TBT agreement and GATS Article VI have an equally open list of justified policy objectives (see TBT Article 2.2 and GATS Article VI:4, discussed supra note 29). Crucially, however, if WTO panels were to make domestic regulation subject to the per se prohibition of quantitative restrictions in GATT Article XI or GATS Article XVI - as happened in US - Gambling did - the limited list of justified policy objectives for such per se prohibitions under both GATT and GATS (respectively, Articles XX/XXI and XIV/XI bis, see supra text at note 27) would be vastly inappropriate, much more so than it is, according to many observers, already today. Moreover, unlike the European Court of Justice or the US Supreme Court, the WTO Appellate Body, which wisely follows a more textual interpretation of the WTO treaty, would find it extremely hard, if not impossible, to widen the list of, for example, GATT Article XX exceptions through case law without legislative input from WTO Members themselves. As noted earlier (see supra text at notes 27-30), this makes the scope of available exceptions another important factor to consider before blurring the line between market access and domestic regulation at the WTO. 
The reason why EC and US laws do not give much weight to the difference between market access and domestic regulation is obvious. As these are much more integrated systems than the quasi-universal WTO, both economically and politically, to strike down domestic regulation based on its trade effects is, in those settings, less controversial and can be remedied more easily. Put differently, whilst the mandate of the WTO does not, in principle, extend to identifying appropriate domestic regulation, the mandate of the EC and especially that of the US does include the harmonization of domestic regulation.

\section{How do disciplines on market access and domestic regulation interact?}

Since the qualification of a measure as either a market access restriction or a domestic regulation can determine its consistency with WTO rules, it is crucially important to circumscribe the confines of these two sets of disciplines. Some measures are clearly market access restrictions, such as custom duties on goods (Article II of GATT) or limitations on the participation of foreign capital in banks (Article XVI:2(f) of GATS). Other measures are without doubt domestic regulation, such as a value-added tax on all goods sold (Article III:2 of GATT), educational requirements to practice medicine, or a driving test to obtain a taxi license (Article VI of GATS).

In contrast, for a considerable number of trade instruments, the distinction between market access and domestic regulation is not as obvious. ${ }^{39}$ For example, is a ban on the importation of asbestos products or shrimps caught without appropriate turtle protection devices (TEDs), in combination with, respectively, a domestic ban on asbestos and an obligation on all domestic fisherman to use TEDs, a border measure or rather the extension of domestic regulation to imports? Equally, as was the situation in the Gambling dispute, is a prohibition on the remote supply of certain gambling services, thereby effectively banning the crossborder supply of such services, in combination with a domestic ban on remote gambling, a market access restriction or rather the extension of domestic regulation to imports?

To provide an answer to these questions a careful examination of, respectively, the relationship between Articles XI and III of GATT and Articles XVI and VI/XVII/XVIII of GATS is required. Whilst some precedents exist on this interaction under GATT, the Gambling case is the very first dispute to address the relationship under GATS. ${ }^{40}$

39 Further complicating the picture is that one and the same measure may fall under both GATT and GATS and be classified differently under each of those agreements. See Joost Pauwelyn, Conflict of Norms in Public International Law (Cambridge University Press, 2003), 399-405.

40 The interaction between GATT disciplines on market access in the form of tariffs, on the one hand, and domestic regulation in the form of internal taxation, on the other, is explicitly regulated and not further addressed in this paper. Article II:2(a) makes it clear that GATT's ban on tariffs above a country's bindings does not prevent 'a charge equivalent to an internal tax' imposed consistently with Article III:2. Read together with the Ad Note to Article III (discussed infra, text at note 41), Article II (tariffs) and 


\subsection{The relationship between Article XI (quantitative restrictions) and Article III (national treatment) of GATT}

1. Domestic regulation that applies to both domestic and imported products is subject to GATT Article III (Ad Note to Article III)

A pivotal factor in determining the relation between Articles XI and III of GATT is the Ad Note to Article III, which provides:

Any internal tax or other internal charge, or any law, regulation or requirement of the kind referred to in paragraph 1 which applies to an imported product and to the like domestic product and is collected or enforced in the case of the imported product at the time or point of importation, is nevertheless to be regarded as an internal tax or internal charge, or a law, regulation or requirement of the kind referred to in paragraph 1, and is accordingly subject to the provisions of Article III. (emphasis added)

Put differently, even if a trade restrictive measure is applied at the time or point of importation, and could therefore be regarded as a border measure subject to Article XI of GATT, it must still be analyzed as a domestic regulation under Article III if, but only if it applies to both imports and like domestic products. ${ }^{41}$

This means in essence that, for measures applied to both imports and domestic products, a preference is given to Article III over Article XI. Given the aboveexplained reasons for, and legal consequences of, the distinction between Articles III and XI of GATT, this preference is entirely logical. In principle, the objectives behind domestic regulation-for example, protecting human health against harmful substances - apply to all products put on the market, be they domestically produced or imported. The sole fact that for imports the regulation is enforced at the time of importation, because it is the only or most efficient time to do so, should not transform the domestic regulation as it applies to imports into a border measure that under Article XI is, in principle, prohibited. Otherwise, all domestic regulation, as it applies to imports, risks being translated into prohibited border measures.

Article III:2 (internal taxes) can, therefore, be regarded as mutually exclusive. The same applies in respect of the relation between, on the one hand, Article II on tariffs and Article III:2 on internal taxes and, on the other hand, Article XI on quantitative restrictions. Article XI:1 is stated to apply exclusively to 'prohibitions or restrictions other than duties, taxes or other charges'. The latter remain subject only to either Article II (tariffs) or Article III:2 (internal taxation). See, for example, the Panel Report on Dominican Republic-Measures Affecting the Importation and Internal Sale of Cigarettes, WT/DS302/R, circulated on 26 November 2004, at para. 7.84 (a point that was not appealed). On the relationship between 'ordinary customs duties' and 'other duties or charges' both referred to in GATT Article II, see the Panel and Appellate Body Reports on Chile - Price Band System and Safeguard Measures Relating to Certain Agricultural Products, WT/DS207/R and AB/R, adopted on 23 October 2002.

41 As noted supra in note 40 this paper does not further examine GATT rules on tariffs and internal taxation: GATT disciplines on tariffs (Article II) and internal taxation (Article III:2) are set up explicitly as mutually exclusive, as are those on tariffs and internal taxation, on the one hand, and quantitative restrictions (Article XI), on the other. 
In other words, the mere fact that a qualitative measure - say, a ban on asbestos or safety specification for cars - also has the effect of restricting the quantity of imports (in casu it bans also imported asbestos or keeps out imported cars that do not meet the safety specification) does not make that measure a quantitative import restriction that is, in principle, prohibited under Article XI. ${ }^{42}$ If the measure applies to both imports and domestic production (i.e., it bans both imported and domestic asbestos or regulates the safety of domestic and imported cars), it must be examined as a domestic regulation under Article III and can, in consequence, only be found to breach GATT rules if it discriminates imports as against domestic products. Because of the Ad note to Article III, the prohibition in Article XI only prevents quantitative restrictions imposed solely on imports (such as a ban or quota on shoe imports without restrictions on domestic shoe production). To apply the Article XI prohibition to all measures, including domestic regulations, on the sole ground that they have the effect of restricting imports would fly in the face of GATT's presumption in favor of regulatory autonomy in Article III of GATT.

This line of reasoning was confirmed in GATT practice. Most prominently, the 1984 Panel Report on Canada - Administration of the Foreign Investment Review Act agreed with Canada that

the [GATT] distinguishes between measures affecting the 'importation' of products, which are regulated in Article XI:1, and those affecting 'imported products', which are dealt with in Article III. ${ }^{43}$

Importantly, the Panel added:

If Article XI:1 were interpreted broadly to cover also internal requirements, Article III would be partly superfluous. ${ }^{44}$

Other panels refused to apply Article XI of GATT to a licensing system for tobacco imports that served merely to enforce domestic quantitative regulations, ${ }^{45}$ to a sixpack configuration requirement on imported beer in Canada, ${ }^{46}$ and to listing and delisting practices restricting imports enacted by state-operated liquor stores in certain parts of the United States. ${ }^{47}$ Each time, instead of Article XI and its presumptive prohibition, the panel applied Article III on the ground that the measure covered both imports and domestic products or did not apply to importation as

42 In contrast to Article 28 of the EC Treaty, which explicitly includes '[q]uantitative restrictions on imports and all measures having equivalent effect'. See supra text at notes 34 and 35.

43 Panel report on Canada-Administration of the Foreign Investment Review Act, L/5504, adopted on 7 February 1984, BISD 30S/140, 162-163, para. 5.14.

44 Ibid.

45 Working Party report on The Haitian Tobacco Monopoly, L/454, adopted on 22 November 1955, BISD 4S/38, 39, para. 9.

46 Panel report on Canada - Import, Distribution and Sale of Certain Alcoholic Drinks by Provincial Marketing Agencies, DS17/R, adopted 18 February 1992, BISD 39S/27, 75, para. 5.4.

47 Panel report on United States - Measures Affecting Alcoholic and Malt Beverages, DS23/R, adopted 19 June 1992, 39S/206, 292, para. 5.63. 
such, but rather to the point of sale. Consequently, in each dispute, the panel only found a violation in case imports were discriminated against domestic products. The Panel on United States - Measures Affecting Alcoholic and Malt Beverages, addressing the listing and delisting practices in certain US liquor stores, put it thus:

[T] he listing and delisting practices here at issue do not affect importation as such into the United States and should be examined under Article III:4 ... the issue is not whether the practices in the various states affect the right to importation as such, in that they clearly apply to both domestic (out-of-state) and imported wines; rather, the issue is whether the listing and delisting practices accord less favourable treatment ... to imported wine than that accorded to the like domestic product. Consequently, the Panel decided to analyze the state listing and delisting practices as internal measures under Article III $: 4 .{ }^{48}$

Although the Appellate Body has not been called upon to rule on the relation between Articles III and XI of GATT, in a number of WTO disputes the question did arise. The Panel on European Communities - Measures Affecting Asbestos and Asbestos-Containing Products ('EC - Asbestos'), agreed with the EC that France's import ban on asbestos fell under Article III, rejecting a Canadian argument that the measure ought rather be examined under Article XI. ${ }^{49}$ Here, as well, the deciding factor was that the ban, though applied for imports at the time of importation, was also applied to domestic products. As a result, the asbestos restriction was not a border measure that is, in principle, prohibited under Article XI. Rather, the panel construed it as a domestic regulation subject to Article III and only found it to be in violation of GATT because, in the view of the panel (subsequently reversed by the Appellate Body), the measure discriminated imported asbestos products (which were banned) against domestic alternatives to asbestos (which were permitted). ${ }^{\mathbf{5 0}}$

In similar vein, the Panel on India-Measures Affecting the Automotive Sector ('India-Autos'), noted:

The use of the term 'importation' in Article XI, rather than 'imports', or 'imported products', clearly suggests that what is targeted in Article XI:1 is exclusively those restrictions which relate to the importation itself, and not to already imported products ... it is the nature of the measure as a restriction in

48 Ibid.

49 Panel Report, EC-Asbestos, WT/DS135/R and Add.1, adopted 5 April 2001, para. 8.93, as modified by the Appellate Body Report, WT/DS135/AB/R.

50 In the Panel Report on United States - Import Prohibition of Certain Shrimp and Shrimp Products (WT/DS58/R and Corr.1, adopted 6 November 1998, as modified by the Appellate Body Report, WT/ DS58/AB/R, DSR 1998: VII, 2821), the question of whether the import ban on certain shrimp (which was at least partly the extension of domestic regulation on US shrimp fisherman to imported shrimp) was a border measure under Article XI or domestic regulation under Article III was not discussed. The US conceded that the ban violated Article XI and based its defense directly on Article XX of GATT. See also Panel Report on United States - Import Prohibition of Certain Shrimp and Shrimp Products - Recourse to Article 21.5 of the DSU by Malaysia, WT/DS58/RW, adopted 21 November 2001, para. 5.20, as upheld by the Appellate Body Report, WT/DS58/AB/RW. 
relation to importation which is the key factor to consider in determining whether a measure may properly fall within the scope of Article XI:1.51

\section{When a measure is subject to the Ad Note to Article III, Article III applies to the exclusion of Article XI}

Although the Ad Note does not explicitly say so, when it directs application of Article III for measures where Article XI could be seen as relevant (since the measure 'is collected or enforced in the case of the imported product at the time or point of importation'), by implication, it must be read as doing so at the exclusion of Article XI. In other words, when the Ad Note does apply and a measure 'is nevertheless to be regarded as ... [one] subject to the provisions of Article III [notwithstanding the apparent relevance of Article XI]', the same measure cannot be subject also to Article XI. At least to this extent, the scope of application of Articles III and XI is mutually exclusive in favor of Article III. ${ }^{52}$ This is illustrated

51 Panel Report on India-Autos, WT/DS146/R and Corr.1, WT/DS175/R and Corr.1, adopted 5 April 2002, paras. 7.259 and 7.261. At the same time, the Panel rejected an argument by India that Article XI only covers 'border measures' in the sense of measures relating to 'the process of importation'. In this case, a so-called trade balancing condition (that is, an obligation to export for the same value that one imports) was found to violate Article XI, although the condition does not relate to the actual 'process' of importation and is not enforced at the time of importation. It sufficed that the condition was a restriction 'in relation to importation' (Ibid., para. 7.262).

52 This does not necessarily mean that Articles III and XI are mutually exclusive in all respects, i.e., that there cannot ever be a measure that is subject to both Article III and Article XI. Indeed, in not a single GATT or WTO ruling can an explicit statement be found to the effect that the scope of application of Article III and Article XI is, in all respects, mutually exclusive. In EC - Asbestos, for example, after finding a violation of Article III, the panel exercised judicial economy concerning Canada's claim of violation under Article XI (Panel report on EC - Asbestos, para. 8.159). In India - Autos, as well, after concluding that India's so-called indigenization requirement violates Article III, the panel did not find it necessary to examine the additional US claim of violation under Article XI (Panel report on India - Autos, para. 7.208). Yet, in both cases the defendant (respectively, the EC and India) considered Articles III and XI to be mutually exclusive. In EC-Asbestos (para. 8.85) the EC put it thus:

either the measure is an internal regulation, in which case it is covered by Article III:4, or it only concerns the import of products, in which case it must be assessed in the light of Article XI:1 ...a single measure that applies both to domestic and imported products must necessarily be covered as a whole by Article III:4 if it is imposed on an imported product at the time or place of importation. Previous practice in the GATT confirms that there can be no cumulative application with Article XI.

For a similar position, taking the view that its Article XI claim should only be examined in case the panel finds that the measure does not fall under Article III, see Panel Report on EC Measures Concerning Meat and Meat Products (Hormones) - Complaint by Canada, WT/DS48/R/CAN, adopted 13 February 1998, at para. 4.354 (arguments by Canada), as modified by the Appellate Body Report, WT/DS26/AB/R, WT/ DS48/AB/R, DSR 1998:II, 235. Yet, especially with the advent of the WTO Agreement on Trade-Related Investment Measures (TRIMs), one could imagine that one and the same measure violates both Article XI and Article III. For example, the trade balancing condition in India - Autos (limiting imports to the value that one exports) was found to violate Article XI (see supra note 51 and TRIMs Agreement Annex Item $2(a)$ ). In addition, however, it could arguably violate also Article III because the limitation on imports favors the use of domestic over imported inputs in car manufacturing (see TRIMs Agreement Annex Item 1(b)). As the trade balancing condition only applies to imports, not to domestic products, the Ad Note to Article III and its corresponding exclusion of Article XI (as depicted in Figure 1 above) do not apply. 
Figure 1. To the extent the Ad Note to Article III directs application of Article III, Article XI cannot apply

Art. III \& Ad Note

(national treatment)

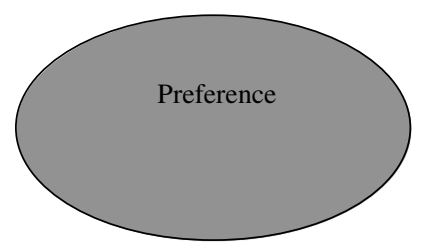

Art. XI (market access)

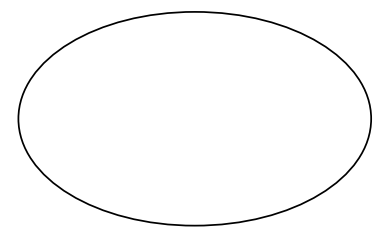

in Figure 1 below, where the tinted section depicts measures which the Ad Note directs fall under Article III, to the exclusion of Article XI. As, from this perspective, Article III gets preference over Article XI, the former is tinted. ${ }^{53}$

The following examples illustrate this point. Pursuant to the Ad Note a ban on asbestos, or requirement to label harmful products, falls under Article III if it applies to both imports and domestic products. If the ban or labeling requirement is subsequently found to be non-discriminatory and therefore not to violate Article III, would it not subvert the very existence of the Ad Note to subsequently apply Article XI and find a violation on the simple ground that the measure also bans or restricts imports $?^{54}$ Put differently, when a trade-related instrument can be qualified as a domestic regulation in the sense of Article III and is non-discriminatory both de jure and de facto, to find that it violates Article XI simply because it has the effect of restricting imports (albeit as much as domestic products) would nullify the basic distinction made in GATT between border measures, which are strictly regulated, and domestic regulation, where broad regulatory autonomy was reserved.

\section{The smoke screen of the unadopted Tuna-Dolphin panel reports}

With the risk of unnecessarily complicating an already complex relation, it is worth pointing out that in two unadopted and subsequently disregarded panel reports, ${ }^{55}$ a peculiar twist was given to the line between Article III and Article XI

Consequently, a violation of both Article III and Article XI could be possible (see Panel Report on India-Autos, para. 7.296 and footnote 433). However, this is very different from making a measure subject also to Article XI even though, pursuant to the Ad Note, it falls under and does not violate Article III.

53 Contrast this preference for GATT Article III (domestic regulation) to the preference under GATS for Article XVI (market access), see infra Figure 3.

54 Although Article XI should not be applied in those two cases, nothing prevents of course that the TBT or SPS agreements apply. As noted earlier, the SPS and TBT agreements discipline domestic regulations including those that are not discriminatory.

55 See Appellate Body Report on US - Shrimp. A recent survey of Article III, albeit focused on tax measures, does not even mention the Tuna-Dolphin reports, see Henrik Horn and Petros Mavroidis, 'Still Hazy after all these Years: The Interpretation of National Treatment in the GATT/WTO Case-Law on Tax Discrimination', 15 EJIL (2004), 39. 
measures. With a view to prohibit what were perceived as extraterritorial trade policies, the Tuna - Dolphin panels (both decided in the 1990s before the WTO's establishment) found that the Ad Note to Article III, and hence Article III itself, only applies to measures that regulate the physical characteristics of the restricted product as such (in casu, tuna and whether it is, for example, toxic). In the view of those panels, the Ad Note does not apply, however, to measures that regulate the way in which the product was processed or produced (in casu, whether or not it was caught killing dolphins, as was the case in this dispute). The first Tuna-Dolphin panel explained this position as follows:

The Panel noted that the [US tuna restriction] regulates the domestic harvesting of yellowfin tuna to reduce the incidental taking of dolphin, but that these regulations could not be regarded as being applied to tuna products as such because they would not directly regulate the sale of tuna and could not possibly affect tuna as a product. ${ }^{56}$

Consequently, the panel found that the US regulations ' did not constitute internal regulations covered by the Note Ad Article III' but rather per se prohibited import restrictions under Article XI.

Much criticism has been raised against the Tuna-Dolphin panel reports. ${ }^{57}$ Their analysis of the relation between GATT Articles III and XI is, however, unlikely to cross over to WTO jurisprudence, in particular since the latter follows a much closer interpretation of the text of the treaty terms at issue. ${ }^{58}$ Indeed, even if the criterion of a regulation has to do with the way a product was processed or produced (rather than the physical characteristics of the product itself), if the criterion is not met and the product cannot, therefore, be imported, it is hard to see why, as the panel found, the measure no longer 'applies to an imported product' in the sense of the Ad Note to Article III. The measure still applies to the product (i.e., the imported tuna is kept out); only the reason why it applies differs (physical characteristic of the product versus a so-called process or production method or PPM). To say that a specific type of reason why a regulation applies to a product means that the regulation itself no longer applies to the product is

56 Panel Report on United States - Restrictions on Imports of Tuna, DS21/R, unadopted, 3 September 1991, 39S/155, para. 5.14. See also Panel Report on United States - Restrictions on Imports of Tuna, DS29/R, unadopted, 16 June 1994, paras. 5.8-9.

57 See, for example, Robert Howse and Don Regan, 'The Product/Process Distinction - An Illusory Basis for Disciplining 'Unilateralism' in Trade Policy', 11 European Journal of International Law (2000), 249-289 and Joost Pauwelyn, 'Recent Books on Trade and Environment: GATT Phantoms Still Haunt the WTO', 15 European Journal of International Law (2004), 575-592.

58 See, for example, Michael Lennard, 'Navigating by the Stars: Interpreting the WTO Agreements', Journal of International Economic Law (2002), 17-89. The Tuna - Dolphin panels may, however, be one of the reasons why the United States in US-Shrimp conceded a violation of Article XI rather than repeating the argument it made in Tuna-Dophin that Article III (and not Article XI) applies. See supra note 50. The United States thereby avoided that a WTO panel or the Appellate Body got into the Tuna-Dolphin question of whether Article III applies to process- or production-related measures, such as a ban on tuna caught killing dolphin or shrimp killing turtle. 
disingenuous. ${ }^{59}$ It leads to a drastic per se prohibition of certain types of regulation solely on the ground of why those regulations are enacted, without any textual foundation in either Article III or its Ad Note (the words 'applies to an imported product' are the only terms relied on in the Tuna-Dolphin panels). In addition, the Appellate Body, in particular in its report on EC-Asbestos, has made it clear that even regulations that distinguish between products based on factors other than physical characteristics can be justified under Article III. ${ }^{60}$ It did so on the ground that those factors can make the products 'unlike' so that treating them differently is not discriminatory and the regulation, therefore, complies with Article III. ${ }^{61}$

\subsection{The relationship between Article XVI (market access) and Articles VI/XVII/XVIII of GATS}

\section{Article XVI (market access) versus Article XVII (national treatment)}

Compared with GATT, the GATS is even less explicit on the relation between its market access provision (Article XVI) and its disciplines on domestic regulation (in particular Articles XVII and VI). More specifically, GATS has no provision comparable to the Ad Note to Article III of GATT. In other words, unlike GATT, the GATS does not state that when a measure affecting trade in services applies to both foreign and domestic services or service suppliers, Articles XVII on national treatment must apply, instead of Article XVI on market access.

The reasons for this omission are clear. First, unlike Article XI of GATT, the scope of Article XVI of GATS includes market access restrictions that apply equally to foreign and domestic services or service suppliers. Of the six market access restrictions exhaustively identified in Article XVI, ${ }^{62}$ only one has an exclusively foreign factor, namely limitations on foreign equity participation (Article XVI:2(f)). The five other Article XVI market access measures are quantitative restrictions

59 The argument that a process-based measure does not 'apply' to the product because it cannot be decided upon inspection of the product which product satisfies the criteria is unconvincing. Physical examinations at customs may not be possible. However, certification or other inspections in the country of origin can distinguish between permitted and excluded products (e.g., between shrimp caught with TEDs and those caught without). The difficulty and trustworthiness of such certification is another issue.

60 The factors traditionally considered in a 'like product' analysis under Article III are: '(i) the properties, nature and quality of the products; (ii) the end-uses of the products; (iii) consumers' tastes and habits ... and (iv) the tariff classification of the product' (Appellate Body Report on EC - Asbestos, para. 101). Note also that in its very first Article III case the Appellate Body rejected the so-called 'aims and effects' test developed in some earlier GATT cases. Like the Tuna-Dolphin panels, this test focused on the aim or reason why a regulation was enacted to decide on compliance with Article III. See Appellate Body Report, Japan - Taxes on Alcoholic Beverages, WT/DS8/AB/R, WT/DS10/AB/R, WT/DS11/AB/R, adopted 1 November 1996, DSR 1996:I, 97.

61 That said, the fact that the process-based distinction of the US ban in the Tuna-Dolphin cases should not have been decisive on the question of whether Article III or Article XI applies, does not necessarily mean that in those cases the panels should have applied Article III. Based on the specifics of the US legislation, in particular whether it could be seen as, in effect, applying equally to imported and domestic tuna, the panel could still have applied Article XI. Yet, in my view, the fact that the US measure was based on a process-related distinction was not sufficient reason to exclude application of Article III.

62 See supra note 16. 
or limitations on forms of legal entity irrespective of whether these restrictions apply only to foreign services or service suppliers (discriminatory market access restrictions) or to both foreign and domestic services and service suppliers (non-discriminatory market access restrictions). Put differently, whilst GATT Article XI only covers discriminatory market access restrictions (e.g., quotas or bans applying only to imports), GATS Article XVI covers, for example, both a measure that limits the establishment of foreign banks to five and a measure that limits the number of all new banks, be they foreign or domestic, to $10 .^{63}$

Second, as much as Article XVI is not limited to market access restrictions that only apply to imports (in contrast to Article XI of GATT), Article XVII is not limited either to domestic regulations (in contrast to Article III of GATT). Indeed, for committed sectors, the national treatment obligation in Article XVII applies 'in respect of all measures affecting the supply of services'. This includes not only internal regulations applying to both domestic and foreign services or triggered only once a foreign service supplier has entered the market. It covers also market access restrictions. Both reasons - in essence, the broad scope of application of market access and national treatment - can, in turn, be explained by the possibility to schedule or reserve measures that would otherwise constitute a violation (an option not provided for in either Article III or XI of GATT). Indeed, with this exit option in mind, to broadly define the scope of market access and national treatment must have seemed less threatening.

As a result, there is a complete overlap in the scope of application of Article XVI (market access) and Article XVII (national treatment) of GATS (to be distinguished from the overlap in actual violations of the two provisions). As shown in Figure 2, all Article XVI measures also fall within the scope of application of Article XVII. This stands in contrast to the, at least partially, mutually exclusive scope of application of Articles III and XI of GATT, where measures directed by the Ad Note as falling under Article III (national treatment) cannot also be subject to Article XI (market access) (see Figure 1 above). Indeed, although in my view incorrectly, some authors have gone as far as claiming that under GATS the opposite is true: namely, instead of national treatment prevailing over market access (as is the case under the Ad Note to GATT Article III), under GATS, once a measure is covered by Article XVI (market access) it cannot be covered also by Article XVII (national treatment). ${ }^{64}$

To illustrate the overlap between Articles XVI and XVII of GATS, a limitation of ten new banks (whatever their origin) is covered by both Articles XVI and XVII, with only the former violated. A limitation of five foreign banks, in contrast, is covered by, and violates, both Article XVI as a prohibited market access restriction

63 See Scheduling of Initial Commitments in Trade in Services: Explanatory Note, MTN.GNS/W/164, 3 September 1993, para. 4 and Aaditya Mattoo, 'National Treatment in the GATS: Corner-stone or Pandora's Box?', 31 Journal of World Trade (1997), 107-135.

64 See infra note 65. 
Figure 2. All Article XVI measures also fall within the scope of application of Article XVII

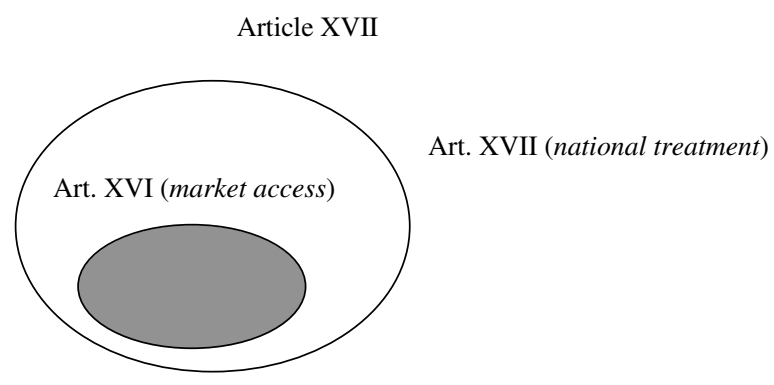

and Article XVII as a discriminatory measure affecting the supply of services. Although, as Figure 2 above shows, all Article XVI measures fall also within the scope of application of Article XVII, Figure 4 below illustrates that a market access restriction prohibited under Article XVI can, but does not necessarily, violate also Article XVII.

The fact that the scope of application of Articles XVI and XVII is not mutually exclusive is further confirmed in Article XX:2 of GATS. It provides that

[m] easures inconsistent with both Articles XVI and XVII shall be inscribed in the column relating to Article XVI. In this case the inscription will be considered to provide a condition or qualification to Article XVII as well.

In other words, if a WTO Member wants to maintain the above referenced limitation on the establishment of foreign banks to five, where it made both a market access and national treatment commitment in the banking sector, that Member must inscribe the limitation in its schedule. Moreover, it will suffice to do so in the column relating to Article XVI. There is no need to repeat the limitation in the Article XVII column. ${ }^{65}$

65 Some authors have deduced a much broader priority rule from this Article XX:2 provision on scheduling. They argue that, based on Article XX:2, Articles XVI and XVII are mutually exclusive in the sense that Article XVII (national treatment) should only apply to measures that do not fall under Article XVI (market access) or, in other words, that preference must be given to Article XVI over Article XVII:

Consequently, measures falling within the scope of market access would-even if they were discriminatory - only fall within the scope of Article XVI and would be excluded from the scope of national treatment. In this case Article XVII would only cover discriminatory measures other than restrictions to market access. A member who remained unbound concerning market access would be allowed to introduce discriminatory quantitative restrictions or other limitations within the scope of Article XVI, because they would be excluded from the scope of Article XVII (Krajewski, supra note 15, at 115. See also Mattoo, supra note 63, at 116).

Two arguments counter this position of mutual exclusiveness between Articles XVI and XVII. First, and most importantly, as noted earlier, Article XVII explicitly states that it covers 'all measures affecting the supply of services'. This, apparently, includes quantitative restrictions subject also to Article XVI. Second, the fact that Article XX:2 expands the reservation of a discriminatory measure under a Member's market access column to a reservation also under its national treatment column confirms, rather than rejects, that 
As applied to the Gambling dispute, for example, even if the US gambling laws at issue were to be construed as market access restrictions under Article XVI (a finding disputed below), such would not preclude the additional application of Article XVII. Put differently, the US gambling laws could, in theory, be both market access restrictions (say, limit the number of suppliers of certain gambling services contrary to Article XVI:2(a)) and discriminate against foreign suppliers of gambling services as compared with like US suppliers of gambling services (contrary to Article XVII). In this sense, a panel can cumulatively apply Articles XVI and XVII of GATS to one and the same measure (see Figure 2 above) even if, importantly, only a commitment was made on national treatment and none on market access. ${ }^{66}$ This is what Antigua asked for. ${ }^{67}$ However, after finding a violation of Article XVI of GATS, the Panel decided to exercise judicial economy in respect of Antigua's national treatment claim under Article XVII. ${ }^{68}$ On appeal, the Appellate Body did not address Article XVII at all. Yet, the ultimate and only reason why it faulted the US gambling laws was one of discrimination, not pursuant to Article XVII, but pursuant to the chapeau of the Article XIV exceptions. ${ }^{69}$

In addition, even if the US gambling laws were found to be non-discriminatory pursuant to Article XVII, such would not, in principle, preclude them from being market access restrictions in violation of Article XVI (quod non). As noted earlier, unlike Article XI of GATT, Article XVI of GATS also covers measures that apply to both foreign and domestic services (e.g., a limit of 10 new banks). Hence, even if a measure is justified as non-discriminatory under Article XVII, it can still be found to violate Article XVI. As Figure 4 below illustrates, some measures may conform to Article XVII but violate Article XVI.

there can be overlap between the two articles. Moreover, to say, as Article XX:2 does, that a specific measure explicitly mentioned and reserved in a market access column can no longer violate Article XVII, is one thing; to say that the absence of commitments under Article XVI means that not a single quantitative restriction can therefore violate Article XVII, quite another. In the first case, other WTO Members, through the reservation under the market access column and Article XX:2, were fully aware that the specific measure would be maintained. The reservation of a specific discriminatory measure in a Member's schedule could, in that case, be regarded as a lex specialis prevailing over the general prohibition on discrimination in Article XVII. In the second case, however, given a full commitment of non-discrimination under Article XVII, WTO Members were entitled not to expect discriminatory measures, including discriminatory quantitative restrictions, even if no commitment was made to an outright ban on all quantitative restrictions (under Article XVI). In that situation, it is hard to construe the absence of commitments on market access as a lex specialis prevailing over an explicit commitment not to discriminate. If anything, it is rather the commitment not to discriminate (under Article XVII) that should prevail as lex specialis over the more general non-commitment on market access (under Article XVI). The normatively neutral objective of 'legal certainty' that comes with two provisions being mutually exclusive, referred to by Krajewski (supra note 15, at 115), can hardly overcome the combined weight of those two arguments.

66 Contrast this to the position referred to, and rejected, supra note 65 , which states that, if a measure falls under Article XVI and no commitments were made under that provision, then Article XVII can no longer apply.

67 Panel Report on US - Gambling, para. 6.422.

68 Ibid., para. 6.426.

69 See supra note 5. 


\section{Article XVI (market access) versus Article XVIII (additional commitments)}

In contrast to the interaction between market access and national treatment in GATS, the relationship between Article XVI (market access) and Article XVIII (additional commitments) of GATS excludes all overlap. Article XVIII itself makes it explicit that additional commitments inscribed in a Member's schedule pursuant to Article XVIII ${ }^{70}$ can only cover ' measures affecting trade in services not subject to scheduling under Articles XVI or XVII'. This is illustrated in Figure 4 below where Article XVIII violations do not overlap with violations under either Articles XVI or XVII.

\section{Article XVI (market access) versus Article VI (domestic regulation)}

Most importantly for present purposes, the GATS does not explicitly regulate how Article XVI (market access) and Article VI (domestic regulation) interact. Some degree of overlap between these two provisions is, however, implied. Article VI:1, for example, covers 'all measures of general application affecting trade in services', thereby apparently including market access restrictions 'of general application' covered also by Article XVI. Articles VI:2 and VI:3, in turn, impose obligations, respectively, for 'administrative decisions affecting trade in services' and situations where 'authorization is required for the supply of a service'. Both provisions would thus seem to cover also certain market access restrictions, or decisions pursuant thereto, that are already covered by Article XVI of GATS.

As a result, one and the same measure (or administration/application of it) can fall under, and violate, both Article XVI and Article VI:1-3 of GATS, as illustrated in Figure 4 below. In the Gambling case, for example, Antigua requested such cumulative application in respect of the US gambling laws at issue, arguing that they violate both Article XVI as market access restrictions and Articles VI:1 and 3 on the ground that the US laws are, inter alia, not 'administered in a reasonable, objective and impartial manner' ${ }^{71}$ However, after finding a violation of Article XVI of GATS, the Panel decided that 'Antigua has not made a prima facie demonstration that the measures at issue are inconsistent with Articles VI:1 and VI:3 ${ }^{72}$ On appeal, the Appellate Body did not address Article VI at all.

The relation between Article XVI and the more substantive parts of Article VI, namely paragraphs 4 and 5 relating to 'qualification requirements and procedures, technical standards and licensing requirements' (hereafter 'QTL requirements'), ${ }^{73}$ is different. It is this relationship that is at the core of the Gambling dispute and underlies the basic argument of this paper.

Market access restrictions are 'maximum limitations' that regulate 'quantity', QTL requirements are 'minimum requirements' that regulate 'quality'

70 For an example, see supra note 19.

71 Panel Report on US - Gambling, para. 6.427-428.

72 Ibid., para. 6.437.

73 See supra text at notes 21-23. 
Focusing exclusively on the quantitative restrictions under Article XVI ${ }^{74}$, the rule of thumb to distinguish Article XVI from Article VI:4/5 measures is that the former relate to the quantity or number of either services or service suppliers (Article $\mathrm{XVI}$ ), the latter to the quality of the service or the ability of the service supplier (Article VI:4/5). Both parties in the Gambling dispute agreed with this distinction and accept that qualitative restrictions are not covered by Article XVI. ${ }^{75}$ The Appellate Body, in turn, confirmed that 'the focus of Article XVI:2(a) is on limitations relating to numbers or, put differently, to quantitative limitations' ${ }^{76}$ As the 1993 Scheduling Guidelines put it (also quoted by the Gambling panel and confirmed by the Appellate Body to be 'supplementary means of interpretation' of the GATS) : ${ }^{77}$

The quantitative restrictions [in Article XVI] can be expressed numerically, or through the criteria specified in subparagraphs (a) to (d); these criteria do not relate to the quality of the service supplied, or to the ability of the supplier to supply the service (i.e. technical standards or qualification of the supplier). ${ }^{78}$

Put more neutrally, that is, completely detached from the regulatory purpose or intent of the measure concerned, Article XVI restrictions impose 'maximum limitations' that cannot be overcome by any action of the supplier (e.g., under a measure limiting new banks to ten, a bank cannot establish itself once the quota of 10 is filled, whatever the bank does). In contrast to such 'maximum limitation', Article VI:4/5 measures impose 'minimum requirements'; that is, they condition entry on specific requirements whose fulfillment is, in theory, in the hands of the service supplier (e.g., a minimum capitalization requirement to obtain a banking license can, in theory, be met by any bank as long as it has the money). ${ }^{79}$

74 This makes abstraction of the limitations on forms of legal entity and foreign equity participation also covered by Article XVI (in paragraphs (e) and (f)).

75 Ibid., para. 6.327.

76 Appellate Body Report on US - Gambling, para 255 and, also para. 248.

77 Ibid., para. 196 (pursuant to Article 32 of the Vienna Convention on the Law of Treaties). The Appellate Body did, however, reject the panel's earlier conclusion that the 1993 and 2001 Guidelines are either 'context' or 'subsequent practice' (or both) in the sense of Article 31 of the Vienna Convention (ibid., paras. 178 and 193). The difference is that the Guidelines as 'supplementary means' can now only be referred to in case the meaning of the GATS provision in question remains ambiguous or leads to absurd results after interpretation pursuant to Article 31.

781993 Scheduling Guidelines, supra note 30, at para. 4. Repeated also in Guidelines for the Scheduling of Specific Commitments Under the GATS, adopted by the Council for Trade in Services on 23 March 2001, S/L/92 (hereafter 'Revised Scheduling Guidelines of 2001') at p. 4.

79 See 1993 Scheduling Guidelines, supra note 30, at para. 5 : ' the quantitative restrictions specified in subparagraphs (a) to (d) refer to maximum limitations. Minimum requirements such as those common to licensing requirements (e.g. minimum capital requirements for the establishment of a corporate entity) do not fall within the scope of Article XVI'. The exception to this rule is Article XVI:2(e) which refers to requirements as to the legal form of service suppliers. 
The relevant parts of the two Article XVI definitions at issue in the Gambling dispute (paragraphs 2(a) and (c)) make the quantitative nature of Article XVI restrictions abundantly clear:

(a) limitations on the number of service suppliers ... in the form of numerical quotas...

(c) limitations on the total number of service operations or on the tot number of service output expressed in terms of designated numerical units in the form of quotas...

Although the GATS itself does not define the meaning of QTL requirements under Article VI, the WTO Secretariat clarified that they regulate quality rather than quantity: Qualification requirements, 'normally relate to matters such as education, examination requirements, practical training, experience or language requirements', ${ }^{80}$ ensuring the quality of the service provider. Licensing requirements 'are substantive requirements, other than qualification requirements, with which a service supplier is required to comply in order to obtain formal permission to supply a service'. Such licensing requirements are stated to include 'residency requirements, fees, establishment requirements, registration requirements, etc.'. Technical standards, finally, 'are requirements which may apply both to the characteristics or definition of the service itself and to the manner in which it is performed'.

This dividing line between quantity/maximum limitations (Article XVI) and quality/minimum requirements (Article VI:4/5) goes back to the aboveexplained rationale for the basic distinction in both GATT and GATS between market access and domestic regulation. The former can be presumed to be protectionist, since they are only applied to imports (such as import quotas under Article XI of GATT) or impose a purely numerical ceiling on whether (more) services can be supplied in the first place (say, a limit on the establishment of five foreign banks, or ten new banks whatever their origin, which, on its face, is a blatant protection of existing banks). ${ }^{81}$ Domestic regulation, in contrast,

80 Note by the Secretariat, The Relevance of the Disciplines of the Agreements on Technical Barriers to Trade $(T B T)$ and on Import Licensing Procedures to Article VI.4 of the GATS, S/WPPS/W/9, 11 September 1996, para. 4. See also Note by the Secretariat, Article VI:4 of the GATS: Disciplines on Domestic Regulation Applicable to All Services, S/C/W/96, 1 March 1999, para. 4.

81 At the same time, unlike the more uniform group of prohibitions and quotas covered by GATT Article XI, it must be pointed out that the six market access restrictions in GATS Article XVI are unlikely to be equivalent in their welfare consequences. As Alan Sykes points out, limitations on the total number of services 'probably have deadweight costs quite analogous to those associated with quotas in goods markets' (Alan Sykes, “ “Efficient Protection” through WTO Rulemaking', in Roger Porter, Pierre Sauve, Arvind Subramanian, and Americao Zampetti (eds), Efficiency, Equity and Legitimacy: The Multilateral Trading System at the Millennium (Brookings Institution: 2001), 114 at 129. However, limitations on the employment of natural persons or requirements to establish a joint venture may have additional types of deadweight costs (respectively, inefficient shift toward capital-intensive technology for service provision and increases in marginal costs of production due to the obligation to team up with nationals of the host 
is presumed to serve a legitimate, non-protectionist purpose, be it consumer protection, safety, or public order. With the exception of blanket bans (on, for example, asbestos or cocaine, both for health reasons), in most cases, domestic regulation assumes that products or services can have market access (they are not per se prohibited) and regulates rather how this can be done (e.g., only faceto-face, not remote gambling is permitted). As a result, domestic regulation, in principle, violates trade rules only when it discriminates against imports ${ }^{82}$ or when it is, for example, more trade restrictive than necessary to meet its stated legitimate objective. ${ }^{83}$

\section{QLT requirements remain subject also to market access disciplines}

Notwithstanding the distinctions set out above, based on the text of GATS, one cannot preclude that QTL requirements governed by Article VI may also be market access restrictions prohibited in Article XVI (remember, GATS has nothing similar to the Ad Note to Article III of GATT). For example, a licensing requirement could take the form of a prohibited Article XVI measure such as an economic needs test (Article XVI:2(a)) or a requirement that the licensee establish a joint venture (Article XVI:2(e)).

The 1993 and 2001 (Revised) Scheduling Guidelines clearly describe Article XVI as a provision that continues to apply notwithstanding Article VI:4/5. ${ }^{84}$ The 2001 Guidelines put it as follows:

Approval procedures or licensing and qualification requirements ... are frequently stipulated as conditions to obtain a license ... they [should not] be scheduled under Article XVI as long as they do not contain any of the limitations specified in Article XVI. However ... [i]f approval procedures or licensing and qualification

country). In contrast, other market access restrictions may be less harmful and imposed for reasons other than protectionism, such as technological limits in the case of limiting the number of providers of audiovisual services. Yet, unlike GATT, which promotes efficient protection by favoring tariff protection over quotas and, in turn, quotas over discriminatory regulation (see supra notes 10 and 11), GATS Articles XVI and XVII treat all market access limitations equally, and do not distinguish between market access restrictions and discriminatory regulation, nor between types of discriminatory regulation (e.g., taxes versus other forms of regulation). As Sykes argues, GATS could do more to channel remaining or permitted protectionism of services industries toward the policy instrument that is most efficient, i.e., least harmful.

82 Article III of GATT and Article XVII of GATS.

83 Under SPS Article 5.6, TBT Article 2.2 or Article VI:4/5 of GATS. The measure may also be WTO inconsistent for deviation from an international standard without justification (pursuant to SPS Art. 3 or TBT Article 2.4). As stated in a Note by the WTO Secretariat, supra note 80, para. 3 :

Measures falling within the scope of Article VI.4. are intended to serve regulatory or other public policy objectives. Their purpose is not to restrict trade, and if they have incidental restrictive effects on trade, Article VI requires that these effects should be the minimum compatible with achievement of the desired policy objective. ... By contrast, measures intended to restrict trade and/or to discriminate between national and foreign suppliers are dealt with under Article XVI, Article XVII and the Annex on Article II Exemptions'. (emphasis added)

84 On the interpretative role of these Guidelines, see supra note 77. 
requirements contain any of the limitations specified in Article XVI, they should be scheduled as market access limitations. ${ }^{85}$

Therefore, unlike GATT, where most, if not all, domestic regulation cannot be subjected to market access disciplines (to the extent the Ad Note calls for application of Article III, it does so to the exclusion of Article XI), under GATS, where both market access and domestic regulation are broadly defined and, as a result, tend to overlap, domestic regulation subject to, and in compliance with, Article VI:4/5 remains subject also to the market access disciplines in Article XVI. In case a WTO Member wants to maintain an Article XVI restriction it must (for committed services) schedule that restriction. A prohibition under Article XVI cannot be cured by Article VI:4/5.

Some would go even further and claim that once a measure falls under Article $\mathrm{XVI}$, it can no longer be subject to Article VI:4/5. ${ }^{86}$ If so, the two provisions would be mutually exclusive with a preference for market access (in stark contrast to the GATT where, to the extent the Ad Note applies, preference is given to rules on domestic regulation over those on market access). This is actually what the Gambling panel found. ${ }^{87}$ Yet, no textual support exists for such mutual exclusiveness and nothing in the current GATS precludes that Article VI:4/5 applies in addition to Article XVI. ${ }^{88}$ In an apparent attempt to move away from this panel finding, the Appellate Body stated that '[i]t is neither necessary nor appropriate for us to draw, in the abstract, the line between quantitative [Article XVI] and

852001 Revised Scheduling Guidelines, supra note 78, at p. 4, emphasis added. Or, as the 1993 Scheduling Guidelines phrase it:

if the criteria for granting licenses or approval [referred to in Article VI:4] contain a market access restriction (e.g. economic needs test) or discriminatory treatment, the relevant measures would need to be scheduled if a Member wishes to maintain them as limitations under Article XVI or XVII (1993 Scheduling Guidelines, supra note 30, at p. 1, emphasis added).

86 See Panel Report on US - Gambling, para. 6.305 and, for example, Laurel Terry, 'But What Will the WTO Disciplines Apply to? Distinguishing Among Market Access, National Treatment and Article VI:4 Measures When Applying the GATS to Legal Services', The Professional Lawyer (2004), 83, at 98 ('Article VI:4 measures that might be the subject of Disciplines are those measures that are neither 'market access' nor 'national treatment' measures, nor subject to any other provision in the GATS, on the other hand').

87 Panel Report on US-Gambling, para. 6.305 ('Under Article VI and Article XVI, measures are either of the type covered by the disciplines of Article XVI or are domestic regulations relating to qualification requirements and procedures, technical standards, and licensing requirements subject to the specific provisions of Article VI. Thus, Articles VI:4 and VI:5, on the one hand, and XVI, on the other hand, are mutually exclusive').

88 Although the panel acknowledged that 'the GATS does not explicitly address the relationship between Article XVI and VI' (at para. 6.307), it found sufficient support for mutual exclusiveness in two quotes from the 1993 and 2001 (Revised) Scheduling Guidelines (supra notes 30 and 78). However, the first quote (at para. 6.307) does nothing more than confirm that the two articles are different. It says nothing about mutual exclusiveness. The second quote (at para. 6.308) is limited to the Accountancy Disciplines or, at the most, to future disciplines to be developed under Article VI:4. It does not explicitly address the present interaction between Articles XVI and VI:5. 
qualitative [Article VI] measures, and we do not do so here'. ${ }^{89}$ Indeed, only the 1998 Accountancy Disciplines, so far the only Article VI:4 disciplines developed by the GATS Council, provide for mutual exclusiveness with Articles XVI and XVII. Paragraph 1 of these Disciplines explicitly states that they

do not address measures subject to scheduling under Articles XVI and XVII of the GATS ... Such measures are addressed in the GATS through the negotiation and scheduling of specific commitments. ${ }^{90}$

Following the example of additional commitments under Article XVIII of GATS ${ }^{91}$, any measure that is a market access restriction specified in Article XVI is, therefore, not covered by the Accountancy Disciplines. As a result, the scope of application of Article XVI and the Accountancy Disciplines is mutually exclusive in the sense that if a measure is covered by Article XVI it cannot be covered also by the Accountancy Disciplines. In the absence of such explicit provision, the same cannot be said about the relation between Article XVI and Article VI:4/5 more generally.

Whether or not GATS disciplines on market access and domestic regulation are mutually exclusive can have tremendous importance. If, on the one hand, Article XVI always applies to the exclusion of Article VI:4/5, then a measure scheduled as a reserved market access restriction under Article XVI is home free and cannot be scrutinized under any additional Article VI:4/5 disciplines. If, on the other hand, Articles XVI and VI:4/5 can, in certain cases, overlap, then even a measure scheduled as reserved under Article XVI could, in theory, still be found to violate GATS because it is, for example, more burdensome than necessary under Article $\mathrm{VI}: 4 / 5$ disciplines. In the latter situation, a conflict could arise between an explicit permission under Article XVI and a prohibition under Article VI:4/5. ${ }^{92}$

89 Appellate Body Report on US - Gambling, para. 250.

90 Paragraph 1, Accountancy Disciplines, supra note 21. Attachment 4 to the 2001 Revised Scheduling Guidelines (supra note 78, at p. 28), entitled 'Discussion of Matters Relating to Articles XVI and XVII of GATS in Connection with the Disciplines on Domestic Regulation in the Accountancy Sector, Informal Note by the Chairman', clarifies this position as follows:

It was observed that the new disciplines developed under Article VI:4 must not overlap with other provisions already existing in the GATS, including Articles XVI and XVII, as this would create legal uncertainty ... the disciplines to be developed under Article VI:4 cover domestic regulatory measures which are not regarded as market access restrictions as such ...

91 See supra text at note 70 .

92 On the need for a wide definition of conflict, see Pauwelyn, supra note 39, at 184-8. To resolve such conflict, one argument could be that the explicit scheduling of the measure under Article XVI prevails as lex specialis over the more general rules in Article VI:4/5. Indeed, at this stage, awaiting further disciplines, Article VI:4/5 can, in any event, not be violated: given that the measure was explicitly scheduled, it must be presumed to be reasonably expected by other WTO Members pursuant to Article VI:5(a)(ii) (see the discussion infra text at note 128). On the other hand, once the GATS Council has developed more detailed Article VI:4 disciplines, one could argue that the prohibition under those disciplines prevails as lex posterior (and arguably also as lex specialis) over the permission under Article XVI. Note that no provision similar to Article XX:2 is at work in this respect. Pursuant to Article XX:2, a measure scheduled 
Figure 3. To the extent Articles VI:4/5 and XVI overlap, a prohibition under Article XVI prevails

Art. VI:4/5 (domestic regulation)

Art. XVI (market access)

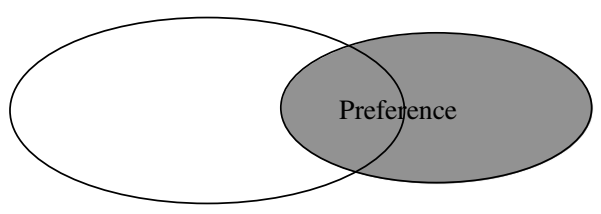

Given those uncertainties, GATS negotiators would be well-advised to follow the example of the Accountancy Disciplines and explicitly regulate, in whatever way they deem appropriate, ${ }^{93}$ the interaction between future Article VI:4 disciplines and Article XVI.

\section{Market access restrictions are, and must be, narrowly defined}

To give preference to market access disciplines over those on domestic regulation, as is currently done in the relation between Articles XVI and VI:4/5 of GATS, poses one serious threat. The risk is that the per se prohibition of market access restrictions under Article XVI encroaches on the regulatory autonomy of WTO Members to set domestic regulation. Indeed, under GATT, the priority rule is the exact opposite. There, to avoid the per se prohibition under Article XI, Article III on domestic regulation largely applies to the exclusion of Article XI (see Figure 1 above) and further SPS/TBT disciplines on domestic regulation prevail over

under Article XVI also counts as a reservation under Article XVII. The GATS is, however, silent about its effect under Article VI.

93 The advantage of carving out Article XVI measures (and discriminatory measures in violation of Article XVII) from the scope of application of future Article VI:4 disciplines is legal certainty, in particular, peace of mind for those WTO Members who scheduled measures otherwise in violation of Articles XVI or XVII. On the other hand, the case could be made that also Article XVI/XVII measures, even if reserved for their quantitative limitation/discrimination in a Member's Article XVI/XVII column, must be subject to further disciplines under Article VI:4 for other aspects. If the relation between the GATT and the SPS/TBT agreements (compared earlier to future disciplines under Article VI:4) is to offer any guidance, SPS and TBT provisions apply in addition to, and cumulatively with, the GATT. Moreover, a Note to Annex 1A of the WTO Agreement provides that, in the event of conflict between the two, SPS/TBT provisions prevail over those in GATT (General Interpretative Note to Annex $1 \mathrm{~A}$ of the Marrakesh Agreement Establishing the WTO). On the relation between GATT and SPS/TBT, see Pauwelyn, supra note 13. In addition, to carve out all market access restrictions from Article VI:4 disciplines (as the Accountancy Disciplines do), even those that were not scheduled or committed and can hence be freely imposed, may offer too much leeway for protectionism by means of market access restrictions, including possibly circumvention of Article VI:4 disciplines through Article XVI measures. At the same time, since many market access restrictions are less costly and more transparent than unnecessary and wasteful regulation, such preference for Article XVI could also be seen as steering WTO Members toward the most efficient instrument of protection (the way GATT steers protection in the goods sector toward tariffs). See supra note 81 . 
GATT ${ }^{94}$ However, to mitigate this risk, and to give effect to the preamble of GATS (which explicitly reserves 'the right of Members to regulate, and to introduce new regulation, on the supply of services within their territories, in order to meet national policy objectives') the types of market access restrictions per se prohibited under Article XVI were narrowly drafted, and must continue to be narrowly defined. Put differently, a contextual interpretation of Article XVI, in the light of Article VI and the GATS preamble, should only apply Article XVI when the measure in question is clearly and explicitly covered as prohibited under Article XVI.

In contrast, the Appellate Body, in its interpretation of Article XVI in Gambling, did not make any reference at all either to Article VI or to the GATS preamble on domestic regulation. Focusing almost exclusively on the text of Article XVI in isolation, it thereby completely ignored the delicate balance, both in GATT and GATS, between market access and domestic regulation. ${ }^{95}$

At the same time, the Gambling Panel did confirm two important limitations under Article XVI. First, the list of six types of measures in Article XVI:2 is an exhaustive one. ${ }^{96}$ If a measure does not fall within one of those six definitions, it is not a prohibited market access restriction, even if in effect it restricts market access. Second, also the elaborations in each of the six definitions are exhaustive. ${ }^{97}$ In particular, limitations on the number of service suppliers are only prohibited if they take the form of (i) 'numerical quotas', (ii) 'monopolies', (iii) 'exclusive service suppliers', or (iv) 'the requirements of an economic needs test'. Equally, limitations on the total number of service operations are only prohibited if 'expressed in terms of designated numerical units in the form of quotas or the requirement of an economic needs test' ${ }^{98}$ Any other limitations on the number of service suppliers or service operations are not per se prohibited.

The mere fact that domestic regulation has the effect of restricting the number of imports does not make it a market access restriction

Whilst the Gambling panel thereby rightly confirmed two limitations under Article XVI, it overlooked another one. This other limitation relates to one of the basic claims in this paper, namely: Domestic regulation, in particular qualification, technical, or licensing (QTL) requirements subject to Article VI:4/5, cannot be found to violate Article XVI as a market access restriction simply because their

94 See also supra note 93.

95 Appellate Body Report on US - Gambling, paras. 223-252. The only non-textual element referred to by the Appellate Body are two examples of Article XVI measures mentioned in the 1993 Guidelines. Ibid., para. 237 (nationality requirements) and para. 249 (restrictions on broadcasting time), discussed infra text at note 121 .

96 Panel on US - Gambling, para. 6.298. The list can be found supra note 16.

97 Ibid., paras. 6.325 and 6.341.

98 The Appellate Body left the question of whether this refers to two or three types of limitations open (ibid., para. 247). 
substantive regulation also quantitatively restricts market access for services or service suppliers that do not meet the requirement. ${ }^{99}$

The following example illustrates this point. If a country requires taxi drivers to pass a driving test, the mere fact that this test keeps taxi drivers that do not pass the test off the market does not make the requirement a market access restriction contrary to Article XVI. This is exactly why Article XVI only prohibits certain formal types of limitations on the number of services or service suppliers, e.g, only those 'in the form of numerical quotas' or 'expressed in terms of designated numerical units in the form of quotas'. Mere quantitative effect is not enough. By finding otherwise, ${ }^{100}$ the Appellate Body effectively read the words 'form' and 'numerical' out of Article XVI. Yet, those words were included with a specific purpose, namely to limit the per se prohibition in Article XVI to explicitly numerical quotas (which, as purely quantitative limits, can be presumed to be protectionist), whilst leaving other non-discriminatory domestic regulations (which can be presumed to serve a legitimate purpose unless proven otherwise) for future negotiations under Article VI.

At this juncture, the relation between Articles VI and XVI of GATS bears similarities with that between Articles III and XI of GATT. As much as the asbestos ban, car safety standard or labeling requirement discussed earlier, all of which apply to both domestic and imported products, does not become a prohibited quantitative restriction under Article XI for the sole reason that it also bans or restricts imported asbestos, cars or non-labeled products, equally, a domestic regulation, related to the quality of a service or the ability of its supplier, does not become a prohibited market access restriction under Article XVI simply because it has the effect of restricting the number of services or service suppliers that can access the market.

To paraphrase the GATT Panel on Canada-Administration of the Foreign Investment Review Act quoted earlier, ${ }^{101}$ if Article XVI of GATS were interpreted so broadly as to cover also the quantitative effects of domestic regulation, Article $\mathrm{VI}: 4 / 5$ of GATS would be superfluous. Indeed, if, following the reasoning of the Appellate Body in Gambling, Article XVI were to include domestic regulation

99 As the Panel on US - Gambling (at para. 6.304) itself noted:

Domestic regulations falling within the scope of Articles VI:4 or VI:5 of the GATS are ... likely to have an effect on market access to the extent that services and service suppliers from other WTO Members which do not, or cannot, comply with such regulations will not have access to the relevant Member's market. Yet, non-discriminatory measures relating to, for instance, the quality of the service supplied or the ability of the supplier to supply the service ... can be maintained provided that they conform to criteria to be developed by the Council for Trade in Services pursuant to Article VI:4 and, in the meantime, to the criteria contained in Article VI:5.

100 Appellate Body Report on US - Gambling, para. 238 ('we are of the view that limitations [in casu, a qualitative limitation on gambling, i.e., a ban on remote gambling] amounting to a zero quota are quantitative limitations and fall within the scope of Article XVI:2(a)') and para. 251.

101 See supra note 43. 
Figure 4. Potential combinations of GATS violations ${ }^{\mathbf{1 0 2}}$

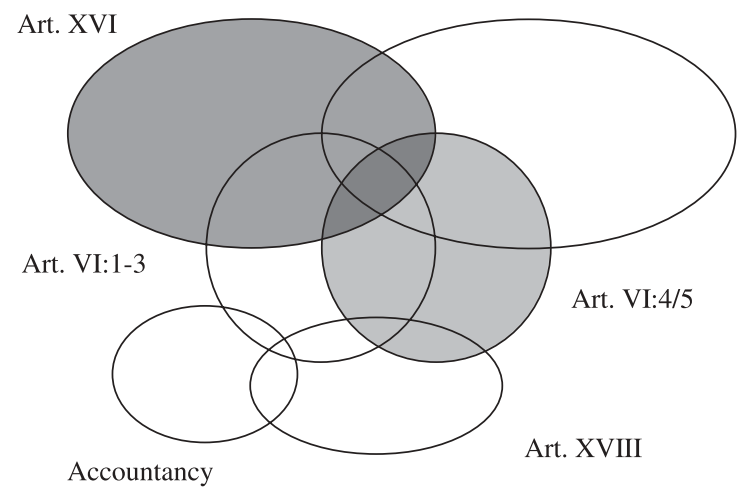

Art. XVII

Article VI:1-3: domestic regulation (transparency and administration)

Article VI:4/5: domestic regulation (substantive disciplines)

Article XVI: market access

Article XVII: national treatment

Article XVIII: additional commitments

Accountancy: 1998 Accountancy Disciplines

simply because it also has the effect of quantitatively restricting the number of services or suppliers that can enter the market, then most domestic regulation would already be prohibited by Article XVI, unless it can be justified under the limited exceptions of Articles XIV and XIVbis. If so, why bother negotiating further disciplines under Article VI:4?

\section{Applying the distinction to US - Gambling}

Applying the above-explained dividing line between Article XVI restrictions (quantity/maximum limitation) and Article VI:4/5 regulation (quality/ minimum requirement), the US gambling laws at issue in the US-Gambling dispute were better defined as technical standards subject to Articles VI:4/5 and XVII. They are not market access restrictions per se prohibited under Article XVI.

102 Figure 4 assumes that the services sector at issue is fully committed under both Articles XVI and XVII. It is also crucially different from Figure 2: Figure 2 depicts the overlapping scope of application of Articles XVI and XVII; Figure 4 depicts potential overlapping violations of GATS provisions (e.g., the fact that all Article XVI measures also fall within the scope of application of Article XVII, see Figure 2, does not mean that all Article XVI measures necessarily violate Article XVII). 
The US laws are domestic regulations that, on their face, apply to both foreign and US providers and are imposed in relation to the quality of the service supplied. They regulate how certain gambling services must be performed, namely by prohibiting their remote supply. They do so to fulfill domestic policy objectives that are, on their face (and as confirmed by the Appellate Body), ${ }^{103}$ not protectionist, namely: concerns of money laundering, fraud, organized crime, and compulsive and under-age gambling. Put more neutrally, and irrespective of their purported regulatory purpose or intent, the US laws do not put a maximum limitation on gambling services in the United States. Rather, they impose minimum requirements as to how those services must be supplied. ${ }^{104}$ As the WTO Secretariat pointed out:

[technical] standards in the area of trade in services apply not only to the technical characteristics of the service itself ... but also to the rules according to which the service must be performed.$^{105}$

This is exactly what the US gambling laws do: They regulate the way in which gambling services must be performed, namely in what one could call an 'inter-personal' or 'face-to-face' manner (the flipside of the prohibition on remote supply). The US laws do so to ensure the quality of the service, in particular to keep minors from gambling so as to protect their health and to protect the wider public order and morality of the United States against fraud and compulsive gambling.

Crucially, the fact that this technical standard of face-to-face supply leads to the prohibition of certain types of supply that do not meet the standard (e.g., the remote supply of gambling), does not transform the technical standard into a market access restriction contrary to Article XVI. As pointed out earlier, as much as a ban on both imported and domestic asbestos, or driving test for taxi drivers, does not become a prohibited quantitative restriction ${ }^{106}$ for the sole reason that it also bans imported asbestos or keeps off the market aspiring taxi drivers that do not pass the driving test. Equally a domestic regulation prescribing how gambling services must be performed does not become a prohibited market access restriction

103 Appellate Body Report on US-Gambling, para. 327 (finding that the US laws before it are 'measures ... necessary to protect public morals or to maintain public order', within the meaning of paragraph (a) of Article XIV of the GATS).

104 That is, the US laws condition the supply of gambling services on specific requirements (i.e., faceto-face or inter-personal supply) whose fulfillment is, in theory, in the hands of the service supplier (the way a minimum capital requirement to obtain a banking license can, in theory, be met by any bank as long as it has the money). Indeed, like US suppliers, Antigua suppliers can supply gambling services in the United States as long as they do so face-to-face.

105 Supra note 80, para. 18. The WTO Secretariat adds, ' $[\mathrm{t}]$ his distinction [between technical characteristics of the service itself and rules on how the service must be performed] is akin to that made in the TBT between product standards and standards relating to production and process methods'. On production and process methods and their coverage under GATT and TBT, see supra text at notes 55 to 61 .

106 Respectively, under GATT Article XI and GATS Article XVI. 
simply because it has the effect of restricting the number of services or service suppliers that can supply the US market (i.e., because it prohibits those not meeting the technical standard).

Yet, it is exactly in this trap that both the Gambling Panel and Appellate Body fell. Even before going into the precise definitions of the six restrictions set out in Article XVI, the Panel had already made up its mind that the US laws are prohibited market access restrictions simply because they have the effect of a prohibition on certain cross-border supplies of gambling services. At paragraphs 6.285-6 the Panel found:

Accordingly, where a full market access commitment has been made for mode 1 [cross-border supply], a probibition on one, several or all means of delivery included in this mode 1 would be a limitation on market access for the mode [under Article XVI] ... If a Member desires to exclude market access with respect to the supply of a service through one, several or all means of delivery included in mode 1 , it should do so explicitly in its schedule. ${ }^{107}$

If this were correct, any domestic service regulation would become a market access restriction simply because it implies 'a prohibition on one, several or all means of delivery' of a committed mode of trade in services, irrespective of whether the regulation falls under one of the six definitions of Article XVI. This, of course, contradicts the Panel's own finding that 'the list of limitations in paragraph 2 of Article XVI is exhaustive' ${ }^{108}$ As Markus Krajewski put it:

A measure which cannot be subsumed under one of the categories mentioned in Article XVI:2 is not prohibited by Article XVI, even if it effectively restricts market access ('de facto market access restriction'). ${ }^{109}$

On appeal, the Appellate Body wisely side-stepped this panel finding ${ }^{110}$ and focused instead on the wording of Articles XVI:2(a) and (c). Yet, it interpreted those provisions in complete isolation of Article VI and the GATS preamble on domestic regulation. Nor did it make any reference whatsoever to the dividing line, so crucial under both GATS and GATT, between market access and domestic regulation. ${ }^{111}$

107 This finding is repeated almost verbatim in the final conclusions of the panel (Panel Report, para. 7.2) without further attention to the specific definitions in Article XVI. Those definitions are dealt with in paras. 6.319-355 of the report, but each time the ultimate reason for finding that the US laws are Article XVI measures is based on the much earlier finding in paras. 6.285-286 just quoted.

108 Panel Report on US - Gambling, para. 6.298.

109 Krajewski, supra note 15, at 84. See also John Jackson, William Davey, and Alan Sykes, Legal Problems of International Economic Relations (St Paul, MN: West Group, 2002), 890 (Article XVI 'focuses on the form of measures, not on their effect', emphasis in original).

110 Appellate Body Report on US - Gambling, para. 220.

111 The Appellate Body stated that '[i]t is neither necessary nor appropriate for us to draw, in the abstract, the line between quantitative [Article XVI] and qualitative [Article VI] measures, and we do not do so here' (ibid., para. 250). Yet, quite obviously, by deciding that a qualitative measure such as banning all remote gambling is, in effect, a quantitative restriction subject to Article XVI, the Appellate Body did draw that line and, in my view, wrongly so. 
Given the exhaustive nature of the enumerations in each of the Article XVI definitions (as confirmed by the Panel itself ${ }^{112}$ ), for present purposes, only limitations 'in the form of numerical quotas' (Article XVI:2(a)) or 'expressed in terms of designated numerical units in the form of quotas'113 (Article $\mathrm{XVI}: 2(\mathrm{c}))$ are prohibited. Nothing else. Yet, through a rather painful stretch of the words 'form' and 'numerical' in Article XVI:2(a), based exclusively on random dictionary definitions (a technique it had earlier condemned as 'too mechanical' 114 when engaged in by the Panel), the Appellate Body effectively redefined 'form' as including 'effect'115 and equated 'numerical' with 'quantitative', ${ }^{116}$ to conclude that 'the thrust of sub-paragraph (a) is not on the form of limitations, but on their numerical, or quantitative, nature'. ${ }^{117}$ Hence, 'limitations amounting to a zero quota are quantitative limitations and fall within the scope of Article XVI:2(a)'.118 In respect of Article XVI:2(c), it found, without real explanation, that the covered limitations 'cannot take a single form, nor be constrained in a formulaic manner' and hence 'catch a measure equivalent to a zero quota'. 119

Unlike the Appellate Body, the Panel at least openly admitted that it went beyond the explicit definitions in Article XVI when finding that 'a measure that is not expressed in the form of a numerical quota ... may still fall within the scope of Article XVI:2(a)', adding that ' $[\mathrm{t}$ ] o hold that only restrictions explicitly couched in numerical terms fall within Article XI:2(a) would produce absurd results' ${ }^{120}$

112 Panel Report on US - Gambling, paras. 6.325 and 6.341 .

113 The Panel referred to a comma in the French and Spanish versions of Article XVI:2(c) to find that also limitation 'in the form of quotas' not 'expressed in terms of designated numeral units' are covered (ibid., para. 6.343-4). The Appellate Body left this question open and assumed, without deciding the issue, that Article XVI:2(c) includes only two limitations, namely (1) 'expressed in the form of designated numerical units in the form of quotas,' and (2) 'the requirement of an economic needs test'.

114 Ibid., para. 166.

115 Ibid., para. 226 (proclaiming, almost metaphysically: " "form” covers both the mode in which a thing "exists", as well as the mode in which it "manifests itself". This suggests a broad meaning for the term "form",). In addition, the Appellate Body referred to other limitations listed in Article XVI:2(a) which allegedly include certain effects as proof that also the notion of 'in the form of ... numerical quotas' must include measures with the effect of a zero quota (ibid., paras. 227-230). Yet, the fact that one limitation includes certain effects does not mean that another does (rather, a contrario).

116 Ibid., para. 227 ('Because zero [the effect of a ban on remote gambling] is quantitative in nature, it can, in our view, be deemed to have the "characteristics of" a number - that is, to be "numerical" '). The Appellate Body thereby read the word 'numerical' out of the phrase 'in the form of ... numerical quotas' as, by definition, a quota is already quantitative (some additional meaning must be given to the word 'numerical').

117 Ibid. para. 232.

118 Ibid., para. 238 (emphasis added).

119 Ibid., para. 247 (emphasis added). The only reason given is that the different limitations summed up in Article XVI:2(c) may overlap. However, the fact that two (or more) definitions may overlap is not a reason to define one of them (i.e., 'limitations ... expressed in terms of designated numerical units in the form of quotas') broadly. If this phrase was not meant to be limited to explicit numerical quotas, it is hard to imagine how any phrase could be so limited (in what way could negotiators have been more explicit?). In sum, the Appellate Body completely ignored the explicit reference to 'designated numerical units'.

120 Panel Report on US - Gambling, para. 6.332. 
Yet, is it up to a panel or Appellate Body to change the explicit terms of a WTO provision simply because it does not like their result?

The 1993 Guidelines seem to have tipped the balance for the Appellate Body. ${ }^{121}$ As an example under Article XVI:2(a), they mention nationality requirements for suppliers of services as a limitation 'equivalent to zero quota'. Besides the fact that the Appellate Body itself found that these Guidelines are not legally binding, and do not constitute agreed 'context' nor 'subsequent practice' but only 'supplementary means of interpretation', ${ }^{22}$ there remains a huge difference, however, between the zero quota explicit in a nationality requirement and the zero quota effect of a ban on all remote gambling. A nationality requirement is nothing but a zero quota on foreigners. The two are exact equivalents and inherently the same. A nationality requirement is, in other words, nothing more than, and can be fully replaced by, a zero quota on foreigners. Its sole object is quantity restriction based on origin. Irrespective of its regulatory purpose or intent, it is a maximum limitation (of zero) on the number of suppliers. In contrast, a ban on all remote gambling, whether domestic or foreign, is not the exact equivalent, nor inherently the same as, a zero quota on cross-border gambling. Because it is a substantive, quality regulation of how gambling services of any origin are to be provided, in addition to a ban on cross-border gambling, it is also a ban on domestic internet gambling. Put differently, US laws on how gambling services must be supplied in the United States (i.e. face-to-face) are more than a ban on cross-border gambling and cannot be fully replaced by a numerical quota: they also ban domestic internet gambling and, crucially, permit non-remote forms of gambling both domestically and from overseas. The zero quota on cross-border gambling is only one of the effects or consequences of the US regulation, not its inherent object. Irrespective of their regulatory purpose or intent, the US gambling laws are not maximum limitations on the number of suppliers or services. Rather, they impose minimum requirements (face-to-face supply) on how gambling must be supplied in the United States. Their object is not quantity restriction, or a ban on cross-border gambling as such; it is quality regulation of both foreign and domestic gambling. ${ }^{123}$

121 Appellate Body Report on US - Gambling, para. 237. Under Article XVI:2(c), the Appellate Body (at para. 249) refers to the example given in the 1993 Guidelines of 'restrictions on broadcasting time available for foreign films'. Yet, nothing in that example shows that Article XVI:2(c) was meant to cover non-numerical restrictions. On the contrary, most restrictions on broadcasting time will be numerical, expressed, for example, in the number of hours channels can air foreign films.

122 Ibid., paras. 178 and 193, see supra note 77. Indeed, in this case one could argue that the text of Article XVI:2(a) leaves no ambiguity, nor does it result in absurdity, so that no reference can be made to 'supplementary means of interpretation' pursuant to Article 32 of the Vienna Convention.

123 That Article XVI:2 only prohibits quantitative restrictions as such, not quantitative effects of other regulations, is confirmed in the 1993 and 2001 (Revised) Scheduling Guidelines which specify that only licensing or qualification requirements that 'contain any of the limitations specified in Article XVI' must be scheduled (see supra note 85, emphasis added) and that the new disciplines under Article VI:4 'cover domestic regulatory measures which are not regarded as market access limitations as such' (see 2001 Revised Scheduling Guidelines, supra note 78, at p. 28, emphasis added). It does not suffice that they have the same effects. Contrast, in this respect, Article XVI of GATS with Article 28 of the EC Treaty which 
Another important reason, especially for the Panel, to broadly define Article XVI limitations beyond their textual scope, seems to be the risk of abuse, that is, the risk that WTO Members rephrase their numerical quotas into substantive regulation so as to avoid the per se prohibition in Article XVI. This risk of circumvention is, however, minimal, if it exists at all. First, if such bogus regulation discriminates foreign as against domestic services or suppliers, be it in law or effect, it will still violate Article XVII (national treatment). ${ }^{124}$ Second, even non-discriminatory regulation must meet the conditions in Article VI:4/5. For example, especially once further disciplines will be developed, such regulation cannot be 'more burdensome than necessary to ensure the quality of the service'. In other words, measures construed to circumvent Article XVI will most likely be weeded out anyhow under Articles XVII or VI. The very objective of Article VI is to develop disciplines on what regulation can and cannot be accepted under GATS. It is not for a WTO panel to prejudge this exercise by qualifying domestic regulation as a per se prohibited market access restriction simply because it has the effect of limiting certain access to the US gambling market.

In contrast, the risk of equating the effect of a zero quota with a numerical quota is very real. It is the slippery slope of confusing form with effect and banning all kinds of domestic regulation not because they are quantitative restrictions, but because they have the obvious effect of keeping certain services or suppliers off the market. Drawn to its logical conclusion, it would mean that a driving test for taxi drivers automatically becomes a prohibited market access restriction simply because aspiring drivers that fail the test do not get a taxi license. Another side effect of this confusion between form and effect is that it may well force WTO Members to treat foreigners more favorably than domestic suppliers, as risks being the case in US - Gambling (where the US could effectively be compelled to permit remote gambling if it originates from overseas, whilst continue to ban remote gambling within the United States).

Finally, the fact that the US ban on remote gambling partly coincides with a complete prohibition on a particular mode of trade in services - in casu, forecloses all of mode 1 or all cross-border trade through the internet or by telephone - does not, by definition, make it a prohibited market access restriction. That domestic regulation, in effect, bans few, a lot or all trade under a particular mode of supply may be relevant to decide whether the regulation discriminates against foreign services or suppliers (under Article XVII) or is 'necessary' to meet its

prohibits '[q]uantitative restrictions on imports and all measures having equivalent effect' (see supra note 34 ).

124 It can make a difference, however, when, for the Member concerned, the specific service sector is committed only under Article XVI (market access) but not under Article XVII (national treatment). In that case, construing a measure as one falling only under Article XVII, not Article XVI, would safe it (although it may still violate Article VI). However, even in that situation, this would seem to be what the WTO Member concerned agreed to: It agreed not to impose the specifically defined market access restrictions, but never committed itself not to discriminate. 
stated objective (under Articles VI:4 or XIV). It is irrelevant, however, for a decision on whether the measure is a domestic regulation or market access restriction in the first place. For that purpose, the only criterion is the six specific definitions in Article XVI:2. To make a GATT analogy, a ban on asbestos equally precludes 'all means of delivery', i.e., all imports normally committed to under GATT Article XI. That does not automatically make it a prohibited import restriction (even if its trade impact may be relevant under GATT Articles III and XX).

A complete ban on internet gambling may, as Antigua argues, not be necessary to fulfill the US objective of face-to-face or inter-personal supply. For example, technological innovation, such as remote voice recognition, eye-scans or encoding may ensure that minors are denied access to gambling sites on the internet. However, it is exactly to answer those questions of scope and necessity of domestic regulation that Article VI:4 calls for further disciplines. ${ }^{125}$ A panel should not prejudge the content of those disciplines nor make their elaboration largely futile by deciding those questions already under Article XVI, in particular, by rephrasing domestic regulation with undesirable market access effects as per se prohibited.

At this point, however, the US gambling laws at issue, although they may violate the non-discrimination principles in Article XVII (a question not addressed in this paper, nor decided in the Gambling dispute), cannot be said to violate Article VI:4/5 (a claim not even invoked by Antigua). As pointed out earlier, ${ }^{126}$ Article $\mathrm{VI}: 5$ only prohibits technical standards

that nullify or impair... specific commitments [under Articles XVI, XVII or XVIII] in a manner which:

(i) does not comply with the criteria outlined in subparagraphs 4(a), (b) or (c); and

(ii) could not reasonably have been expected of that Member at the time the specific commitments in those sectors were made. ${ }^{127}$

The second condition for the US laws to violate Article VI:5 - explicitly stated to be cumulative to the first (because of the word 'and'), is not fulfilled. All US laws at issue pre-date the point in time where the United States made its GATS commitments. Hence, since they were already in place, all of these laws could 'reasonably have been expected of [the US] at the time the specific commitments' were made.

125 Questions of necessity of the US laws may also be examined under Article XIV (e.g., is the measure 'necessary to protect public morals'), as the Panel did (Panel Report on US - Gambling, paras. 6.475 ff.). However, as noted earlier (see supra text at notes 27-30), once defined as a market access restriction, the possible justifications for it under Articles XIV/XIV bis are much narrower than those available for domestic regulation under Article VI. Hence, although the measure may still be justified under Article XIV, to wrongly qualify it as a market access restriction whilst it is in fact domestic regulation automatically narrows the scope of justifications for it and shifts the burden of proof to the regulating country.

126 Supra text at note 23.

127 Emphasis added. 
This reading is confirmed in a Note by the Secretariat stating that indent (ii) of Article VI:5(a) 'seem[s] to exempt from Article VI:5 at least all those measures which were already in place in $1995,{ }^{128}$

\section{Conclusion}

It is surprising that so basic and important an interaction as that between WTO disciplines on market access and domestic regulation is not more firmly regulated in either GATT or GATS. For good economic and political reasons, market access restrictions such as custom duties, import quotas, and restrictions on the number of services or service suppliers are, and should be, tightly disciplined. To the extent committed, they are, in principle, prohibited. In contrast, in the diverse setting of 150 WTO Members, domestic regulations such as internal taxes, health or environmental measures, technical specifications for standards and rules on how a service must be performed are, and should be, handled with extreme care. The WTO only prohibits them when they discriminate against imports or, for some areas, when they are, in essence, more trade restrictive than necessary. ${ }^{129}$

Given the consequences, confusing domestic regulation for a market access restriction - the way, in my view, the Panel and Appellate Body in US - Gambling and, to some extent, the Tuna - Dolphin panels, did - risks to seriously endanger the regulatory autonomy of WTO Members to an extent not envisaged by the drafters of the GATT/WTO treaties.

In an attempt to draw a brighter line between the two disciplines and thereby to avoid inappropriate encroachment of WTO panels on the regulatory autonomy of WTO Members, this paper proposes the following rules.

First, under GATT, a measure that applies to both imported and domestic products must, pursuant to the Ad Note to Article III, be subject to Article III, not to Article XI. For example, a ban on asbestos, or shrimp caught killing turtle, that applies to both imported and domestic asbestos/shrimp is a domestic regulation subject to the non-discrimination provision in Article III:4. It is not a per se prohibited quantitative import restriction under Article XI simply because it also restricts imported asbestos or shrimp. At least to this extent, Articles III and XI of GATT are mutually exclusive. This rule should apply irrespective of whether the measure relates to the physical characteristics of the product or its process or production method. The Tuna-Dolphin panels that held to the contrary should be, and in effect have been, set aside.

128 Note by the Secretariat, Article VI:4 of the GATS: Disciplines on Domestic Regulation Applicable to All Services, S/C/W/96, 1 March 1999, para. 11.

129 Under the SPS or TBT agreements for trade in goods, under Article VI of GATS for trade in services. 
Second, under GATS, to the extent committed, any measure affecting the supply of services must be non-discriminatory (under Article XVII) and any measure meeting one of the six specific definitions of market access restrictions (under Article XVI) is prohibited (unless justified under Articles XIV and XIV bis). Crucially, in contrast to GATT, Article XVI of GATS (market access) also applies to measures that cover both foreign and domestic services or service suppliers. Hence, the fact that a measure is indistinctly applicable to imports and domestically - as seems the case for the US laws in the Gambling dispute-does not dis-apply a Member's market access obligations. Equally, since Article XVII (national treatment) covers all measures affecting services, including market access restrictions, one and the same measure can violate the rules on both market access and national treatment, and the absence of commitments under market access does not prevent a violation of national treatment.

The central criterion to distinguish the market access restrictions subject to Article XVI and qualification, technical or licensing requirements under Article VI is that the former explicitly and directly relate to quantity or whether one can at all have access to the market (e.g., a limit of 10 new banks), the latter regulate the quality of the service or the ability of its supplier, that is, how a service must be supplied. Irrespective of the regulatory purpose or intent of the measure concerned, Article XVI covers maximum limitations, Article VI:4/5 minimum requirements. Although the two types of measures can overlap (licensing requirements may, for example, take the form of market access restrictions), their interaction is not explicitly regulated in the GATS. A contextual interpretation demonstrates that, in contrast to GATT, domestic regulation under GATS remains subject also to market access disciplines. Conversely, with the exception of the 1998 Accountancy Disciplines, no textual support can be found to exclude domestic regulation disciplines as soon as a measure is a market access restriction. To provide legal certainty, it is important that any future disciplines on domestic regulation explicitly regulate their relationship to Articles XVI and XVII. The important differences in this respect between GATT and GATS are largely explained by GATS' broad (and, therefore, overlapping) scope of application of both market access and domestic regulation which, in turn, can be explained given the exit option provided for, only in GATS, to schedule or reserve measures that would otherwise be violations.

Given the continued application of market access disciplines even to domestic regulation, to preserve the regulatory autonomy of WTO Members under GATS it is, however, crucially important to narrowly define prohibited market access restrictions. If not, regulatory freedom under Article VI risks being emptied through per se prohibitions under Article XVI. The list of six restrictions in Article XVI is exhaustive, as is the enumeration under each of those six definitions. In addition, services measures, in particular qualification, licensing or technical requirements and procedures (as defined in Article VI:4) are not prohibited market access restrictions simply because their qualitative regulation of a service or its supplier also 
has a quantitative effect on the services or suppliers that can enter the market. For example, a driving test for taxi drivers or requirement that gambling occurs faceto-face - respectively a qualification requirement related to the ability of the supplier and a technical standard on how a service must be performed, both subject to Article VI - are not market access restrictions per se prohibited under Article XVI simply because they also restrict the number of taxi drivers (by excluding those that fail the driving test), or the number of gambling services and suppliers (by excluding remote gambling).

It can only be hoped that the Appellate Body will be willing and able to distinguish the US laws in Gambling - i.e., the effect of a complete prohibition or zero quota that fully coincides with a particular mode of services supply, in that a ban on remote gambling includes a ban on all cross-border trade - from other domestic regulation with a less drastic quantitative effect. ${ }^{130}$ This will, however, require creative interpretations of the Appellate Body ruling itself and no longer be based on the text of the GATS which, in turn, may draw the criticism of judicial activism. In this sense, the damage is done but room for correction remains available.

130 At para. 232 the Appellate Body may be hinting at such distinction ('This is not to say that the words "in the form of" should be ignored or replaced by the words "that have the effect of", '). 